\title{
El entremés de El juez de los divorcios y otros infelicísimos malcasados
}

\author{
José Enrique LóPez Martínez*
}

El texto de El juez de los divorcios que abre el conjunto de piezas breves en el volumen de las Ocho comedias (1615) ha sido principalmente estudiado como una reflexión o una disertación sobre las virtudes, límites y defectos de la institución matrimonial, y en este sentido, ha sido puesto en relación con otras obras de nuestro autor en que se refiere al matrimonio o expone la vida de parejas mal concertadas, como las que en sentido burlesco serán representadas en el entremés. Derivado de ello, varios especialistas han visto en esta obra incluso una defensa de la mujer frente a las ideas, costumbres o estructuras sociales que le daban un papel inferior frente al hombre en la época ${ }^{1}$. En pocas ocasiones, sin embargo, esta y otras de las piezas breves cervantinas han sido analizadas de forma individual en el contexto de sus propias influencias literarias ${ }^{2}$. Estas líneas tienen como objetivo situar el primero de los entremeses cervantinos en el marco de los textos, principalmente teatrales, que pudieron

* Universidad Nacional Autónoma de México.

1. En fechas más recientes, algunos críticos han sugerido nuevas perspectivas de estudio al situar la pieza en el contexto de los debates teológicos sobre el divorcio del XVI, con sus implicaciones legales (Restrepo-Gautier, 1995-1997); la realidad jurídica y procesal de la separación matrimonial (Atienza, 2004); o la influencia de textos como el Ingenio para las ciencias de Huarte de San Juan (Pérez de León, 2005), aunque todos mantienen el mismo enfoque de fondo de entender el entremés principalmente como una reflexión, entre burlas y veras, acerca del matrimonio y el divorcio en la España del siglo XVII. Sobre la supuesta defensa de la mujer que hace Cervantes también insiste Chul (1999). Menciono solamente algunos de los trabajos más recientes dedicados a la obra. En ellos y en las distintas ediciones modernas de los Entremeses se puede consultar en detalle la amplísima bibliografía que la crítica cervantina le ha dedicado.

2. Una excepción es el citado trabajo de Pérez de León, que relaciona brevemente El juez de los divorcios con otros entremeses de jueces o de examen, como el Hospital de los podridos o El triunfo de los coches de Gaspar de Barrionuevo, que se mencionarán más adelante. 
aportar elementos para su configuración como obra esencialmente cómica, y de las que denotan una posible influencia, a su vez, de este entremés. Sobre la pieza que nos ocupa, al margen de la revisión de su verosimilitud jurídica, legal o costumbrista, y su posible relación con determinados debates de su tiempo, veremos que el conocimiento de las principales obras literarias con las que interactúa puede ofrecer elementos de valor para entender más cabalmente los propósitos estéticos de Cervantes y la interpretación que recibiría por parte de los lectores de su época ${ }^{3}$.

El argumento de El juez de los divorcios, como se recordará, consiste básicamente en la aparición de este juez, con sus oficiales, escuchando consecutivamente a tres parejas y a un hombre que se presentan a solicitar su divorcio y exponer sus motivos -los defectos de sus respectivos cónyuges-, todo ello en un tono claramente cómico y burlesco. Esa sucesión de casos se basa en una estructura común en el género del entremés, que es la del desfile de figuras, y específicamente en el formato del juez o fiscal satírico, como ha sido ya señalado en numerosos estudios. Tal diseño relaciona nuestro entremés con otras piezas bien conocidas hoy, como el anónimo Hospital de los podridos o el Miser Palomo de Hurtado de Mendoza, en cuanto a la forma general señalada, y en tratándose de jueces y fiscales específicamente, con El comisario contra los malos gustos de Salas Barbadillo o El comisario de figuras, de Castillo Solórzano, por citar solo un par de ejemplos.

Además de esas estructuras, sobre las que volveremos más adelante, varios de los especialistas que han analizado el entremés cervantino han señalado como modelo central el motivo literario de las discusiones o rencillas entre casados, aunque con frecuencia sin aducir textos específicos de tales posibles antecedentes ni dedicarles un estudio detallado. En efecto, principalmente a través del cuento en sus diversas manifestaciones -facecia, conseja, patrañaeste motivo básico aparece ampliamente desarrollado en la literatura de todo el siglo XVI, como señaló M. Chevalier (1983:191-258). En ese estudio encontraremos un extenso apartado de «Cuentos de casados» que alimentarán en gran medida la caracterización de los personajes en los que se basará Cervantes para su entremés. Probablemente en el cuento antes que en el teatro aparecerán descritas situaciones narrativas en las que se representa una discusión o una pelea entre esposos, habitualmente rústicos, siempre por un motivo muy concreto: algo relacionado con la comida, con el gobierno de la casa, con diferencias de opinión ${ }^{4}$. Pero en su paso a las tablas o a los corrales,

3. Aun así, el trabajo de Atienza ofrece datos de mucho interés en lo que respecta al carácter de la intervención de los jueces, las causas más comunes para conceder un divorcio, y la posible frecuencia con que se viviría este proceso en la cotidianidad de la sociedad áurea.

4. En el inventario que ofrece el profesor Chevalier se pueden identificar además determinados grupos temáticos dentro de los cuentos de casados: engaños al marido, a veces tonto, por parte de la mujer infiel y su amigo; mujer brava que termina siendo domada por el esposo; alguna prueba que hace este a su mujer (fidelidad, humildad, comportamiento tras su falsa muerte). La cuentística, a diferencia de la mayoría de las obras teatrales, dará preferencia a una situación en la que uno de los dos esposos sufre al otro, y por esa misma razón al final de la anécdota uno resultará triunfador. Los 
esas breves discusiones conyugales trascenderán lo anecdótico para convertirse en peleas conformadas por catálogos generales de los defectos de ambos esposos, y con ello formular un cuestionamiento del propio matrimonio, como veremos muy frecuentemente en la tradición de malcasados de la que formará parte la obra cervantina.

En este sentido concreto, los primeros referentes claros para el escritor alcalaíno parecen haberse desarrollado sobre todo en el propio género teatral antes que en el cuento. El más importante sin duda entre los antecedentes dramáticos españoles para El juez de los divorcios es la Farsa de la Costanza, de Cristóbal de Castillejo -como ya ha señalado con acierto Rosario Martínez Navarro (2007)-, obra de fecha incierta pero escrita verosímilmente en el primer tercio del siglo XVI. La pieza del poeta castellano desarrolla muy por extenso los dos elementos centrales del diseño de El juez de los divorcios: la representación de matrimonios mal avenidos, y el recurso inverosímil o fantástico a una posible anulación del vínculo, en este caso en forma de un cambio final de esposas entre los dos protagonistas varones. La relación con el texto de Cervantes se puede apreciar mejor con el reciente descubrimiento y edición de un testimonio completo de la Farsa, hasta ahora conocida solo por el resumen y los versos que había transcrito Leandro Fernández de Moratín de otro manuscrito, hoy perdido, antes estante en la Biblioteca del Escorial ${ }^{5}$. En Castillejo, la formulación de las desavenencias matrimoniales será más sencilla y tópica que en Cervantes, ya que estará basada principalmente en la diferencia de edad de los casados, rústicos típicos del teatro del XVI: un viejo con una moza, y un joven con una vieja, la Costanza del título; y en ambos casos, se hará especial énfasis en la insatisfacción sexual de las dos protagonistas, en consonancia con el tono más burlesco, desenfadado y grotesco de la obra de Castillejo ${ }^{6}$. Después de los actos I y II -en la versión hoy recuperada del texto- en que se exponen respectivamente las peleas de Antón y Marina, y de Gil y Costanza, la Farsa presenta un largo sermón burlesco de tema amoroso en donde el fraile que se encargará de hacer el «arreglo» final de las parejas expone precisamente esta solución: una supuesta indulgencia concedida por el Papa para matrimonios infelices - una estafa, en realidad, para engañar a los rústicos, se nos dirá adelante-. Es el germen del planteamiento fantástico y

malcasados teatrales en cambio tendrán predilección por las situaciones en las que ambos padecen y al tiempo dan mala vida a su pareja.

5. El descubrimiento del texto fue dado a conocer por Cristiana Aresti (2005), y poco después fue descrito con más detalle por María Teresa Cacho y Blanca Periñán (2006). La obra ha sido finalmente editada por Blanca Periñán y Rogelio Reyes (2012), donde ofrecen un panorama más detallado de la historia de la obra y su crítica. Citaré los fragmentos de la Costanza por esta edición, modernizando algunas grafías y puntuación. El mismo procedimiento de modernización se seguirá en algunas de las citas posteriores de otras obras.

6. Martínez Navarro hace una comparación detallada de las quejas de los pleiteantes del entremés cervantino y las que aquí presenta Castillejo, especialmente en los primeros actos de la Costanza, además de otros aspectos como las caracterizaciones respectivas de maridos y mujeres, y de las figuras de autoridad en ambas obras. 
satírico del tribunal divorciador cervantino, con su parodia de las formas y el lenguaje legal de la época:

Y por tanto / siendo el Padre nuestro Santo / sabidor de tantos males, / viendo que son generales / y general el tal llanto / de las gentes, / por quitar inconvinientes / y dalles algún reposo, / como padre pïadoso / con los amantes presentes / y futuros / que tienen amores duros / y malos de disgestión, / porque de más perdición / al menos estén seguros, / si quisieren, / y porque no desesperen / los que están mal empleados [...] ha mandado / que cualquier enamorado / que le va mal con su amiga / le pueda dar una higa / sin quedar excomulgado; / y ella a él / si no le hallare fiel / o le viere andar roncero, / le tenga por chocarrero / y por vano cascabel / con tal prueba [...] Íten quiere / que el marido que estuviere / de su mujer descontento, / reniegue del casamiento / cuantas veces él quisiere; / y dispensa / que ella para su defensa / tomar pueda arma cerruna, / y que ponga cada una / en efecto lo que piensa / y desea (pp. 171-174) ${ }^{7}$.

El cuarto acto de la obra presenta una discusión entre los dos hombres rústicos sobre una burra que, sabremos de inmediato, Antón quiere que tome Gil por ventaja para el cambio de las esposas, que tratan y acuerdan aquí mismo; en el cierre de la Farsa se desarrolla la burlesca liturgia del cambio, precedido de una larga disputa en la que Costanza se niega a tal acuerdo aduciendo muy serias razones sobre la indisolubilidad del matrimonio, lo cual termina de apuntalar el sentido irónico del texto. He aquí sendas citas de los momentos más importantes de estos actos:

ANTÓN. [...] Cuanto monta a nuestra cosa / pardiós, este y yo venimos / a deciros que vivimos / una vida fatigosa / enfenita; / él tiene una vejecita / que le pone en mil coidados, / yo tengo, por mis pecados, / una zagala maldita, / por mojeres; / él tiene cien mil aferes, / yo más que puedo llevar, / porque no podemos dar / comprimiento a sus praceres / suelta renda; / no curan de la facienda / són [sino] de su cachondería, / y con esto cada día / tenemos fuerte contienda / y cuestiones; / arrógame mil baldones, / que nunca su boca calla, / yo, triste, por contentalla / tengo ya los compañones /

7. Periñán y Reyes (2012: 255) indican que la indulgencia papal del texto de la Farsa podría ser una alusión satírica a las concedidas a Enrique VIII después de sus varios divorcios, y también a Felipe de Hesse, que Castillejo critica en otras obras, quien repudió con autorización de Lutero a su mujer Cristina de Sajonia. Castillejo, como se ve, se mantiene más cerca del plano realista de la ficción - a diferencia de lo que hará Cervantes- al explicar la inverosímil disolución de los matrimonios como una estafa a los rústicos, pero sin duda que la creación literaria de la posibilidad del divorcio burlesco es creación original del poeta. Sobre este final, y adelantando un poco nuestras propias conclusiones, vale la pena citar el juicio de Periñán y Reyes, igualmente válido para lo que sucede en el entremés cervantino: «En efecto, el enredo de la Costanza (un trueque matrimonial supuestamente sacralizado por la misma clerecía) es cualquier cosa menos verosímil, pero el crudo realismo de los cuatro personajes campesinos, tanto en sus rústicos comportamientos como en sus toscos discursos, pueden trasladar al lector una engañosa impresión de veracidad», p. 41.

Solamente en los casos de piezas de teatro tempranas del XVI citaré en bloque los versos (algunos demasiado cortos), para no exceder la paginación de este estudio. 
desollados, / mas aunque tengo quebrados / los lomos y colcosilla, / no me tiene más mencilla / que a los muertos sepultados / so la tierra (pp. 239-240).

Cura. [...] Vos, Gil, tomad de la mano / a Costanza que está ahí, / y entregadla luego aquí / a Antón como buen hermano / sin porfía, / y decid sin cobardía / tres veces, como yo hablo: / «yo te entrego este diablo / de la peña Camasía». / Vos, Antón, / por igual satisfación, / le daréis a Gil Matiego / a vuestra Marina luego, / en el nombre y bendición / de San Pablo, / y decid, como lo entablo, / tres veces con alegría: / «Pues yo te entrego esta mía, / que tiene por su vocablo, / pestilencia» (p. 303).

Así pues, creo que no puede haber duda acerca de la influencia del texto de Castillejo en el entremés de Cervantes y antes de aquel en varios otros textos, como a continuación veremos; no es inverosímil suponer que nuestro autor pudo conocer el texto de la Costanza, aunque solamente circuló de forma manuscrita, en España o en alguno de sus bien conocidos contactos con Italia, donde Castillejo pasó un tiempo considerable de su vida y donde al presente se halló el segundo testimonio conocido de la Farsa ${ }^{8}$. La idea de un matrimonio desastrado no es desde luego original del poeta renacentista, pero muy probablemente sí lo es su representación o su escenificación teatral, y con la intención concreta de diseñarlo como un recurso cómico, que será parte fundamental del camino que nos llevará hasta Cervantes.

Además de las secuencias de parejas peleando, y de la inverosímil ficción del rompimiento matrimonial, junto a otros motivos menores, el texto de Castillejo será parte esencial del desarrollo de un tipo de personaje que tendrá presencia habitual en la literatura española posterior 9 . De las dos parejas de la Costanza, y concretamente de las dos mujeres, no será la uetula la que ejercerá más influencia en otros textos, sino más bien la joven Marina, en su calidad de malcasada furiosa e intratable, tipo que comienza a aparecer en las letras castellanas en estos años del XVI ${ }^{10}$. Seguramente anterior a la Farsa

8. Martínez Navarro es más cauta a este respecto: «Sería arriesgado decir que Cervantes conocía la obra de Castillejo, pues no encontramos referencia alguna, pero sí que recurre a un motivo que el poeta renacentista muchos años antes había cultivado de manera muy similar», art. cit., p. 45.

9. La Costanza presenta también motivos que aparecerán frecuentemente en textos análogos, como el maldecir en plena discusión a las personas que concertaron el matrimonio: «MARINA. Que no, no, / que quien con vos me casó, / que le dé Dios mal provecho: / no lo fizo con derecho, / porque era chiquita yo», pp. 90-91; «CostanZA. [...] ¡quien me pesguñó con él, / fizo terrible pecado!», p. 114. También la queja de la mujer de ser la única malcasada: «MARINA. ¡Malfado que me cubrió / sobre todas las moyeres / del logar; / nos vos podés meniar / ni sos bueno para nada», «llores a Dios por ello, / pocas son las malcasadas, / priado veré quitadas / estas pesgas de mi cuello», pp. 88, 280; y finalmente, las palizas del marido a su mujer, tema constante en la Costanza (I, vv. 130-164; II, vv. 293-339; IV, vv. 421-460; V vv. 836-837) y en muchas otras obras. Cabe decir aquí que no todos los motivos comentados en este estudio aparecerán estrictamente en El juez de los divorcios, pero son considerados en tanto que elementos recurrentes en otros textos de la tradición literaria de malcasados graciosos de la que pienso que la obra cervantina forma parte.

10. En otro trabajo, Chevalier (1984:201-203) habla de una forma constante de representación misógina de la casada, que se dividiría a su vez en representaciones de la «guerrilla conyugal» y del miedo a la mujer, a través de los personajes de la casada parlanchina y golosa, la tonta, la porfiada, o la mujer taimada y demoniaca. Las Marinas que tendremos en nuestra tradición se corresponderían 
es la extensa caricatura de la malcasada que hace el compadre gracioso de la Comedia del viudo de Gil Vicente (1513), que sale para expresar la envidia que siente del viudo:

COMPADRE. ¡Si yo tengo un animal, / pese a tal, / y una sierpe por mujer! / Y por más mi daño ser, / es inmortal. / Tanto monta dar en ella / como dar nesa pared; / cuanto más riño con ella, / tanto más se goza ella. / Para Dios me hacer merced, / no tiene hambre ni sed: / más que una red, / siempre harta y aborrida. / Si esta vida tal es vida, me sabed. / Cuando con ella casé, / hallé, norabuena sea, / en ella lo que os diré: / cuando bien bien la miré, / vile un rostro de lamprea, / una habla a fuer de aldea, / y de Guinea / el aire de su meneo; / cuanto más se pon darreo, / está más fea. [...] Ella, por «dadme esa paja», / mete la calle en revuelta; / seso, ni sola migaja; / dueña que se volvió graja, / y anda en el aire suelta. / Hállola muy desenvuelta / en dar vuelta / dende lo bueno a lo malo: / lleva infinito palo / nesta envuelta [...] Si algo estoy de placer, / dice que yerba he pisado; / si triste, quiéreme comer. / Yo no me puedo valer, / así me trae asombrado. / Yo, se trayo a mi cuñado, / convidado, / muéstrame un ceño tamaño / que me hace andar un año / reñegado. / Yo no la puedo trocar, / yo no la puedo vender, / yo no la puedo amansar, / yo no la puedo dejar, / yo no la puedo esconder, / yo no le puedo hacer entender / sino que es ella una rosa, / y que está muy desdichosa / en mi poder (pp. 122-125) ${ }^{11}$.

También en el teatro, años después, se repite una descripción genérica muy semejante por parte de otro rústico en el introito del anónimo Auto de Clarindo, publicado probablemente hacia 1535:

Es gran trabajo, / metellas por el atajo / ninguno, por más que viva: / ¡envialdas cuesta bajo, / que ellas han d'ir cuesta arriba! / Terná locura / el hombre que las procura; / aman jay! a repujones: / la que dice no, si jura, /

con la casada porfiada que menciona el gran erudito francés, y veremos también ocasionalmente rasgos de los otros tipos. En el catálogo de cuentos de casados notamos que algunos tipos específicos se acercan particularmente al tipo de la malcasada furiosa, como en los cuentos (según la terminología de Chevalier) «La mujer ahogada», «Tijeretas», y «El marido enérgico». Estos cuentos tienen antecedentes tan antiguos e ilustres como el Exemplo XXVII de El conde Lucanor, «De lo que contesció a un emperador et a don Álvar Háñez Minaya con sus mujeres», después también incluido en el Corbacho (II, VII).

11. Como se ve, la idea del «canje» ya se le había ocurrido a este malcasado, que tal vez tenía presente Castillejo para su farsa, así como el carácter de la mujer feroz. Es más que posible que este texto ejerciera su influencia directamente en los ingenios áureos, ya que se publicó en la Compilação de Gil Vicente, en sus dos ediciones de 1562 y 1586, además de que hay noticia de posibles ediciones sueltas anteriores; v. el «Prólogo» de M. Calderón a la edición, pp. XLIX-LI. Mucho menos frecuente será la sátira desde la perspectiva de la mujer, pero una muestra temprana aparece también en Gil Vicente, en el Auto de la Sebila Casandra (ca. 1513): «Veo quejar las vecinas / de malinas / condiciones de maridos: / unos, de ensobervecidos / y aborridos; / otros, de medio galinas; / otros, llenos de mil celos / y recelos, / siempre aguzando cuchillos, / sospechosos, amarillos / y malditos de los cielos. / Otros, a garzonear / por el lugar / pavonando tras garcetas, / sin dejar blancas ni prietas / y reprietas. / ¿Y la mujer? Sospirar. / Después, en casa, reñir / y groñir, / y la triste allí cautiva. / ¡Nunca la vida me viva / si tal cosa consentir!», pp. 86-87; y la canción Dicen que me case yo: / no quiero marido no, de los vv. 198-217, p. 89. 
sus pares han de ser nones. / Profiadas / son, y tan indiabladas / que por mal se han de regir; / aunque las matéis a porradas, / no las haréis ni aun erguir. / ¡Pues, andar, / que si empiezan a temear / y a no comer a la mesa / ni en la cama se acostar, / por salir con su impresa, / estarán / un mes que no os hablarán / són con el hocico tuerto, / y harán que no comerán / y tragarán más que un puerco! / Pues allegar / la hacienda y multiplicar, / ansí viva mi agüelo, / són, si las dejáis gastar, / lo pornán todo del duelo / muy aína; / no recogen la harina, / són procúranla derramar, / y la ceniza ayuntar / y reñir con su vecina. / Por no nada, / una vecindad yuntada / os allegará por muy poco, / que al hombre tornará loco / en vella desenfrenada (pp. 214-215) ${ }^{12}$.

Los personajes que nos ocupan, los malcasados cómicos, fueron poblando poco a poco los escenarios teatrales del XVI, pero también aparecieron en textos en prosa de muy distinta naturaleza. Para ver mejor otra rama importante del desarrollo de esta historia hay que volver un poco atrás en el tiempo, hasta mediados del siglo XV. Varios pensadores y predicadores de la época, como en muchos otros tiempos, se ocuparon de tratar abundantemente la idea del amor, el matrimonio y los problemas comunes de la vida marital; sin embargo, algunos de esos textos, de la misma forma que alimentaron la noción cervantina y de otros autores del matrimonio cristiano, también pudieron aportar elementos para la configuración literaria de los malcasados ridículos que veremos en el teatro del XVII, al aproximarse con una intención no necesariamente estética a lo que sin duda también debió ser una realidad cotidiana, y con ello complementar los tipos que ya iban surgiendo en la ficción. El primer gran antecedente de importancia en este sentido es el Arcipreste de Talavera (a su vez, reformulación hispánica de varias fuentes europeas de discursos misóginos), que con su magnífica herencia de tipos y habla popular también contribuyó a la llegada de la casada mal acondicionada que veremos en el primer teatro castellano; especialmente en el segundo libro, dedicado a los vicios femeninos, el Corbacho anticipa muchísimos de los rasgos y quejas que protagonizarán las malcasadas teatrales, especialmente la envidia hacia las otras mujeres, el sacar a cuento la dote, y el martirio de ser la única malcasada del mundo, cosas todas que se reprochan al marido:

que ya la mujer del menestral, si ve la mujer del caballero de nuevas guisas arreada, aunque no tenga qué comer, cayendo o levantando, ella así ha de facer o morir. Non son sinón como monicas: cuanto ven tanto quieren facer. «iViste Fulana, la mujer de Fulano, la vecina, cómo iba el domingo pasado? Pues iquemada sea si este otro domingo otro tanto non llevo yo, e aun mejor!» [...] E si el marido con menester empeña alguna aljuba o manto della, o cinta o otra alfaja, aquí son los llantos, aquí son los gemidos, los rezongos, los zaheríos, lágrimas e maldiciones, diciendo: « ¡Ay sin ventura de mí! Non ove yo ventura como mi vecina, que en guar de medrar desmedro; en guar de facerme paños nuevos, empéñasteme estos

12. Indica el editor del Auto, Miguel Ángel Pérez Priego (p. 32), que fueron Gayangos y E. de Vedia quienes sugirieron la fecha de 1535, basándose en las características materiales del impreso. 
captivos que en la boda me distes, e tales cuales ellos son. ¿Esto esperaba yo medrar convusco? ¿Así medran las otras?» [...] Pero si el cuitado del marido, padre o amigo non lo puede ganar, a su oficio non se corre, e para mantener a ella ha menester algunos dineros e empeña sus balandranes, su espada, sus armas, el jubón, las botas, fasta las mezquinas, o vende su casa, viña o campo o heredad, allí non dan voces, non hay maldiciones, lágrimas nin gemidos (pp. 152-153).

¡Aquella, aquella es amada e bien amada, que non yo, triste, cuitada! Todo ge lo dio Fulano, su marido: por cierto que es amada. ¡Ay, mezquina y triste de mí, que amo e non so amada! ¡O desaventurada! Non nascen todas con dicha: yo mal vestida, peor calzada, sola, sin compañía; que una moza nunca pude con este falso alcanzar [...] e lo peor es que non soy conoscida nin presciada, soy desfavorecida. Pues otro era mi padre que non era su ahuelo. ¡Loado sea Dios que me quiso tanto mal! Mi ventura lo fizo; que si Dios andoviese por la tierra, treinta mil en ajuar truje e en dineros contados, e aquella en camisa la tomó su marido. Peor só que amigada, nunca más medré de esta saya, que esta otra que tengo, perdone Dios a mi padre, que él me la dejó y él se la ganó. Pues, ¿qué medré, amigo, después que estó con vos? Fadas malas, filar de noche e de día (pp. 155-156).

También fundamental será la aportación del Corbacho de su descripción de los tres casamientos reprobados (III, 9), en donde veremos las quejas que la moza hace de los achaques de su marido viejo, que llegarán a la Costanza y a la primera pareja del entremés cervantino:

«Nunca otro casamiento faga quien este casamiento me adilgó» [...] Apaga la candela, échase cabe dél, e vuélvele el rostro, e dale las espaldas diciendo:

«iMala vejez, mala postrimería te dé Dios, viejo podrido, maldito de Dios e de sus santos, corcobado y perezoso, sucio e guargajoso, vellaco y enojoso, pesado más que plomo, áspero como cazón, duro como buey, tripudo como ansarón, cano, calvo e desdentado! ¿Y aquí te echaste cabe mí, diablo desazado, huerco espantadizo, puerco invernizo, en el verano sudar e en el invierno temblar? ¡Triste de la que tal heredo tiene! ¡Guay de la que tal posee! ¡Ay de la que tal cada noche al costado tiene! ¡Oh triste de mí, que en hora mala nascí! ¡Y para mí fueron guardadas, cuitada, estas fadas malas! ¡Otra logró su mocedad, y para mí, captiva, estudo guardada esta mala vejedad! [...] Yo non puedo creer que más desaventurada mujer en el mundo nasció. ¡Ya mi marido mozo e zapatero fuese, pobre e sin dinero, e non fuese este diablo que tengo! ¿Qué me aprovecha su riqueza, cuitada? ¿Su fidalguía qué me vale? ¡Ya guaya! Pues que al mejor tiempo sola me fallo e desacompañada, fago cuenta que con mi comadre duermo, como solía» (pp. 226-227).

Entrado el siglo XVI, y coincidiendo temporalmente con los primeros malcasados del teatro, otros importantes tratadistas retomarán varias de estas estampas del Arcipreste; pero lo que en el Corbacho se presenta para condenar globalmente el amor desordenado y el comportamiento de las mujeres será retomado mayormente por otros autores con un objetivo en sentido contrario, es decir, ofrecer consejos matrimoniales. Así sucede, por ejemplo, en el Relox 
de príncipes de fray Antonio de Guevara (1529), obra fundamental en la configuración del imaginario sobre las esposas de mal carácter que poblarán toda la ficción el siguiente siglo:

Por lo que he leído y por lo que he visto, diría yo que do el marido y la mujer viven bien avenidos no solo se pueden llamar buenos casados, mas aun llamarse hombres sanctos; porque (hablando la verdad) son tantas las cargas del matrimonio, a que no se pueden cumplir sin mucho merescimiento. Lo contrario se debe y se puede decir de los que son malcasados, a los cuales los llamaremos no compañía de sanctos, sino casa de demonios; ca la mujer que tiene mal marido faga cuenta que tiene en su casa el demonio, y el marido que tiene alguna mujer mala faga cuenta que tiene el infierno en su casa. Y digo que las mujeres malas son peores que las infernales Furias porque en el infierno no atormentan sino a los malos, pero las mujeres indómitas atormentan a malos y buenos (p. 354).

La más doméstica rencilla que hay entre el varón y la mujer es sobre que él querría guardar la hacienda para comer y para a sus hijos criar, y por contrario, ella no querría sino gastarla toda en vestir: porque en este caso las mujeres son tan curiosas y tan amigas de se vestir que ayunarían y se absternían de los alimentos de la vida solo por sacar una ropa nueva para un día de fiesta [...] No es mi fin de hablar aquí de las vestiduras sino para persuadir a las señoras que, si quisiesen ellas estarse recogidas en sus retraimientos, escusarían estos superfluos gastos; porque de ver una mujer que su vecina va mejor vestida que no ella se torna contra su marido como una leona. Acontece muchas veces lo que pluguiese a Dios que no viésemos acontescer, y es que si viene una inopinada fiesta o una regocijada justa no da la mujer a su marido vida hasta que le saca para aquel día una ropa; y como el pobre señor no tuvo dineros para la pagar, hubiéronsela de necesidad de fiar; y como se pasase la vanidad de la fiesta y se llegase el tiempo de la paga, hobiéronle de afrentar la persona y dar a ejecutar la hacienda [...] Pocas veces tiene una mujer envidia de otra mujer porque es más hermosa, o porque es más generosa, o porque es más valerosa, o porque es mejor casada, ni mucho menos porque es más virtuosa, sino solo porque la otra anda mejor vestida que ella; porque en caso de vestir no hay mujer que tenga paciencia en que otra menor se le iguale ni que otra su igual le sobrepuje (pp. 383-384) ${ }^{13}$.

13. Se trata de dos breves estampas que por su tono familiar tendrían hasta cierto sentido cómico para los lectores del XVI, pero aparecen en un tratado muy serio y extenso de Guevara sobre la vida matrimonial. Dentro de este Relox de príncipes, los consejos sobre el matrimonio y la crianza de hijos ocuparán todo el segundo libro, de tres que conforman la obra. No cabe duda acerca de su importancia para la formación de un tipo cómico sobre la malcasada burlesca, que como iremos viendo tendrá en este uno de sus rasgos más constantes: como pocos autores en la tradición hispánica, Guevara hace del mal carácter el principal defecto de las mujeres y a él dedica la gran mayoría de sus advertencias para los príncipes y plebeyos al momento de elegir estado -aunque no deja de aceptar muy ligeramente varios de los defectos que se aprecian en los esposos, habitualmente para recomendar tolerancia de parte de la mujer-. También Guevara habla con frecuencia de las formas de reprehensión que ha de haber entre los esposos, y de la necesidad de evitar las discusiones públicas, que será otro motivo que pasará a nuestra tradición literaria en sentido cómico.

A posición equidistante entre el teatro cómico pastoril y los tratados serios sobre el matrimonio parece situarse la singular Farsa del matrimonio, de Diego Sánchez de Badajoz (¿1552?). Esta obra 
Más cercana a la creación literaria mencionada será la descripción de los escándalos de pareja que hace hacia 1550 Pedro de Luján en sus Coloquios matrimoniales - con toda seguridad ya bajo la influencia del texto de Guevaraespecialmente en el énfasis que pone en la participación de los vecinos y el carácter público de las discusiones, otros elementos que aparecerán en el teatro, tanto extenso como breve, de algunas décadas adelante ${ }^{14}$ :

Mas mucho mejor es no quejarse, sino con amorosas palabras reprehenderse; quejarnos a nuestros vecinos no es otra cosa sino dar ocasión a que si nos quieren mal tomen placer, y si nos quien bien tengan qué decir. Hay hombres tan mal mirados, y mujeres tan mal sufridas que ni ellos saben reñir sino voceando como locos, ni ellas responder sino gritando como desatinadas, de forma que el oficio de los vecinos es apaciguarlos entre semana, y oír sus quejas cada día. Quejas en el casado. Quéjase el marido diciendo que su mujer es brava, que no hay demonio que con ella pueda; quéjase que es celosa y sospechosa, que no puede con ella hacer vida; quéjase que es impaciente, deslenguada, y a cada paso lo deshonra [...] Por otra parte, como la mujer no tenga manos para se vengar, sino lengua para hablar, quéjase de su marido que es triste, cetrino, malencónico, mal acondicionado, que no caben con él los vecinos, ni le pueden sufrir los de casa; que es bravo, mal sufrido, que a las mozas apalea y a ella destoca; quejase que la llama fea, y otras injurias que en contarlas le faltan lágrimas del corazón; quéjase que no la deja ir a ver a sus padres, ni aun a misa; quéjase que es celoso, sospechoso, que no la deja parar a la puerta ni a la ventana, ni vestir una saya, ni poner una toca, sino que la hace estar guardada como una doncella; quéjase que no le agradece servicio que le haga, ni le cree cosa que le dice, porque si está enojado a todos desmiente, y cuanto tiene en las manos arroja; quéjase que no deja mujer casada, ni viuda, ni soltera, ni moza, a quien no sirva y a quien no siga... (p. 157) ${ }^{15}$.

En el camino que llegará hasta la obra cervantina, y de vuelta al teatro, cabe mencionar algunas de las piezas del «gran Lope de Rueda», influencia señaladísima y bien conocida de nuestro autor. Acaso siguiendo textos como $L a$ Costanza, o en todo caso otras obras sobre casados rústicos del teatro y del cuento del XVI, como los de Gil Vicente, Rueda presentará discusiones cómicas entre

alternará, sin solución clara de continuidad, secuencias serias como el debate teológico entre los dos esposos rústicos sobre la preeminencia del hombre, y las advertencias matrimoniales del frayle, con escenas de contenido cómico como la pelea de insultos y casi golpes del matrimonio de pastores, y la caracterización burlesca del religioso lascivo.

14. El aspecto teatral o público que se explota en el entremés de Cervantes, y la descripción particular de la mujer como escandalosa, han sido ya notados por Atienza (2004: 201-202).

15. La caracterización de los malcasados varones será más diversa que la caricatura monotemática de las malcasadas, pero encontraremos algunos rasgos que tendrán cierta recurrencia, como el supuesto mujeriego que se describe en el texto de Luján y que ya habíamos visto también en las quejas de Costanza: «Sodes un desoluto / con mil rapazas por ahí / y cuando venís a mí / facéisvos un santo puto / muy beato. [...] conmigo sodes parlero, / conas otras facendoso, / conmigo muy reguroso / con otras falaguero / y apacibre; / para mí sodes terribre, / mas para Toribia no, / pues no so tan vieja yo», p. 109. Este motivo también reaparecerá en la pareja de Álvaro e Ipólita de Los malcasados de Valencia de Guillén de Castro. 
esposos en al menos tres de sus piezas: Las aceitunas, La fiesta del Corpus Christi, y la secuencia de Los linajes dentro del Coloquio de Camila. De ellos, el más cercano sin duda a lo que veremos en el entremés cervantino será la pelea de Los linajes, que aunque parte de un motivo concreto, como era común en la tradición cuentística -aquí, la desaparición de un pollo por supuesto descuido del marido- se llega a la representación de la gresca ante los vecinos y a otros reproches más generales sobre el matrimonio:

Ginesa. Eh, callad, ánima de campana.

PABLOS. ¿Qué es ánima de campana, mujer?

Ginesa. ¿Qué? Badajo, como vos.

PABlos. ¿Badajo a vuestro marido? Deme ese garrote vuesa merced.

GinEsA. ¡Así! ¿Garrote para mí? Al fin no seríades vos hijo de Guarnizo, el ensamador, cura bestias. [...]

Pablos. Sí señor. ¿No ve vuesa merced que soy todo entero hijo de Guarnizo el ensalmador, que aunque la señora Ginesa dice que curaba bestias, levántaselo, que no era sino medio albéitar? Mas pregúntele vuesa merced a ella, veamos cúya hija es.

GinEsA. Costáraos a vos un ojo y del otro no viérades nada y fuérades de tan buen generación como yo.

PABLOS. ¿Quién eran tus padres? Dilo, veamos.

GinESA. ¿Quién? Esteban de Bolaños, regidor en Pliego, y Lucía Hernández de Saldaña, honradísimos ambos si los había en todo el lugar.

PABlos. ¡Ah! Noramaza, señora mujer, levantéis tan falsos testimuños a vuestros padres. ¿No se te acuerda que cuando te casoren conmigo te me dioren por hija de Logroño el aceitero? Y aun se me miembra que no sé sobre qué medidas falsificadas que tu padre hizo le dioren cien azotes y de comer aquel día.

GinESA. ¿Cien azotes? Levantáronselos en verdad.

PABLos. Levantáronselos o asentáronselos, allá se los llevó a su casa.

Socrato. Amo, no habéis por tan poco de deslindar linajes.

PABLos. Calle vuesa merced, que juro por el cielo de Dios bendito que si no le atajáramos que mos hiciera encreyentes que era hija del conde Hernan González o de Belerma. Por mi mal fuiste engendrada.

Socrato. Ora, ama, entraos allá dentro (pp. 192-194) ${ }^{16}$.

16. El título de Los linajes fue propuesto por García Pavón para esta subtrama, que se sigue desarrollando en otras dos escenas del coloquio Camila (aunque solo en la primera se da la situación de malcasados); en el segundo fragmento, Pablos baila y canta los versos «Más trabaja que el que cava / el que tiene la mujer brava». Por otra parte, el paso de Las aceitunas, cuyo título se debe a su vez a Moratín, es una reformulación muy original de la «fábula de la lechera» influida sin duda por los malmaridados graciosos y rústicos, pues traduce en una pelea conyugal el antiguo motivo cuentístico de hacer «castillos en el aire»; cfr. sobre este cuento, Fradejas (1978).

Junto a Rueda, también Joan Timoneda tiene una importante participación en la historia que vamos trazando, con su adaptación de Plauto, Comedia de los Menennos (incluida en sus Tres comedias de 1559). En el original latino ya se encontraba la descripción de un matrimonio tormentoso, y en menor medida de una mujer celosa y mal acondicionada. Pero Timoneda, cuya versión actualizaba estos motivos para la tradición teatral castellana de mediados de siglo, no se limita a copiar estas secuencias, sino que, por una parte, les da más importancia en la obra (especialmente en la escena de intervención del suegro, en Plauto una sola secuencia, que el valenciano convierte 
Estos matrimonios desastrados, y principalmente la figura de la malcasada feroz no deben confundirse con otra tradición bien conocida, y con la que comparte solo ciertos elementos accesorios: las quejas de la malcasada. Esta temática se desarrolla a lo largo del XVI especialmente a través de la poesía, aunque su extenso recorrido llegará hasta los grandes clásicos a través de la novela pastoril o incluso el propio teatro, como en la comedia La bella malmaridada (1597) de Lope de Vega ${ }^{17}$. Esta tradición coincide con su par burlesco del teatro en el motivo de las quejas de la dama joven y bella por los sufrimientos que le ocasiona su marido, normalmente un viejo o un hombre demasiado celoso; pero en el ámbito de los malcasados, como vamos viendo, esas endechas tristes y estilizadas caminarán hacia el terreno de lo costumbrista y se extenderán a ambos miembros del matrimonio, convirtiendo lo que era un motivo triste y trágico en la malcasada en un esquema con intenciones fundamentalmente cómicas. A pesar de ello, también la malcasada de la lírica puede llegar al sentido jocoso que veremos en el teatro, y a dar un espacio a la idea de la anulación del matrimonio o el divorcio, en un sentido siempre utópico o inverosímil ${ }^{18}$.

Todas aquellas obras de ficción sobre malcasados graciosos, y con el cimiento particular de la Costanza, debieron alimentar la creación de un esquema de situaciones en los que se podrá incluir una variedad indeterminada de personajes, pero que se define dentro de los límites de unos pocos elementos: las quejas de ambos miembros de la pareja por los defectos de su compañero, en el contexto de una satirización frecuente del carácter de cárcel o tormento del matrimonio, y el tipo específico de las malcasadas indómitas, como las llamó fray Antonio. Tal esquema adquirirá un brío particular en los albores de la Comedia Nueva, donde nos iremos encontrando con algunas piezas, anteriores a El juez de los divorcios, que manifiestan la influencia de los textos y tradiciones comentadas, y que anuncian varios otros de los elementos que veremos en la pieza cervantina. La primera de ellas debe ser el anónimo Entremés de los huevos, publicado en la Tercera parte de comedias de Lope de Vega, Madrid, 1613, aunque seguramente representado en las tablas muchos

en dos discusiones separadas con los respectivos cónyuges); y por otra, los amplía con otros elementos relacionados con los personajes de los malcasados que se habían visto tanto en el cuento como en el teatro previos. Sucede, por ejemplo, con la descripción de los defectos de las mujeres que el suegro refiere a Menenno (esc. III); o la inclusión del motivo de las «yerbas» alegóricas que el padre recomienda a su hija para tener a su esposo contento (esc. VII), variante del cuento «El agua maravillosa» que Chevalier (1983: 240-242) documenta en la época también en el Buen aviso y portacuentos del propio Timoneda.

17. De esta tradición se han ocupado, entre otros, Pilar Lorenzo Gradín (2004), Lourdes Albuixech (2008), y Robert Lauer (2005). La obra de Lope, dicho sea de paso, se basa casi solo nominalmente en el romance para construir un argumento de enredos ambientado en la corte madrileña, pero mantiene el tono serio y de conmiseración hacia la dama fiel maltratada por su esposo que es común en la lírica.

18. Por ejemplo, en las coplas populares: «A la malcasada / Dios le dé placer, / que la bien casada / no lo ha menester», «Una ley bien ordenada / nos han dado por abrigo: / que cualquiera malcasada / pueda tener un amigo», recogidas en Frenk (2003: 199, 1297). 
años antes ${ }^{19}$. Situado también en el ámbito de los personajes simples o rústicos heredados del primer teatro del XVI, este entremés no aludirá todavía a la posibilidad de divorcio o separación de los irreductibles esposos, pero el centro del argumento lo constituirá la pelea entre sus dos protagonistas -pelea incluso a golpes, como se ve en otros textos- en torno a un motivo absurdo: la negativa de la mujer a comer los huevos que ha pedido su marido, siempre en el contexto del escándalo y de intervención de vecinos y sacristán. Desde la primera escena se nos representa la desavenencia burlesca, aunque inusualmente violenta, entre Benito y Menga, y con ello la sátira sobre el matrimonio y los necios malcasados en voz del propio sacristán:

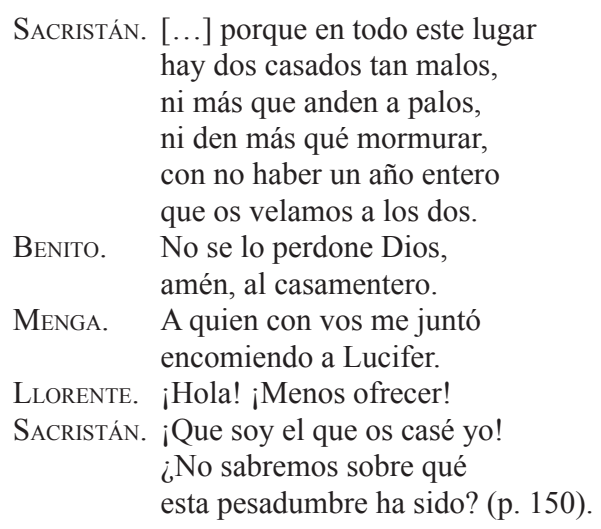

El comienzo de tal pesadumbre será relatado en voz de Menga, a quien en las primeras escenas hemos visto más como víctima de los arrebatos de su tozudo marido; el dramaturgo, sin embargo, también pondrá énfasis en el carácter impetuoso de la mujer, como otras de sus parientes literarias, para terminar la configuración de pareja de malcasados de esta pieza breve anterior a la de Cervantes. Todo comienza en una promesa de parte de Benito de llevarla a las fiestas de Corpus de Sevilla:

MENGA. $[\ldots]$ Cuando ya la burra estaba
aguardando que la cinche,
trujo Benito unos huevos
para almorzar; yo le dije
que no pensaba fréillos
por no llenarme de tizne,

19. Chevalier (1983:210-213) recoge un cuento análogo, en la versión del Fabulario de Sebastián Mey (1613), con el título «¿Quién comerá el tercer huevo?», y lo pone en relación con el entremés. No sé si la anécdota o anécdotas sean de origen folclórico, pero en todo caso de estas dos versiones literarias, publicadas en el mismo año, la de Mey parece ser posterior y acaso fue escrita sin que el autor valenciano conociera la pieza breve; su texto se aleja mucho de la caracterización rústica de los esposos, que en el entremés todavía manifiesta con claridad su relación con las tradiciones teatrales del XVI. 


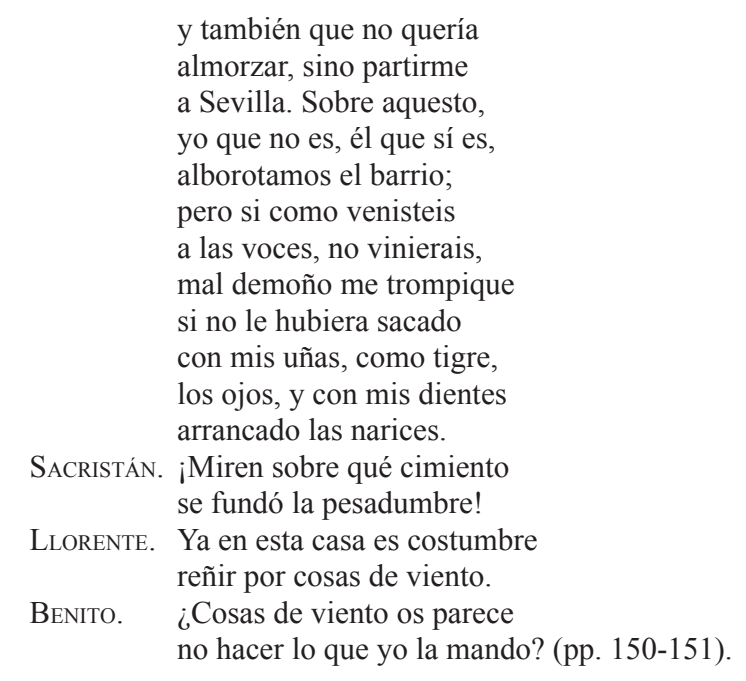

Después de lo que el espectador ha escuchado en escena, o el lector en letras de molde, no sería necesario insistir demasiado en el carácter igualmente explosivo de Menga para terminar de configurar el personaje de la mujer brava y de la pareja de malcasados, que se reforzará en el resto del texto. Tras una breve tregua, en la que Menga acepta preparar los huevos y los esposos salen de escena, se hace un breve paréntesis para mostrar los preparativos que a su vez ese pequeño pueblo hará para la fiesta de Corpus ${ }^{20}$; sin embargo, volveremos pronto a las pesadumbres de Menga y Benito cuando se dé la negativa de la zagala a comer los tales huevos, que aunque no son representadas adquieren trazos vivísimos en la narración del primo Llorente:

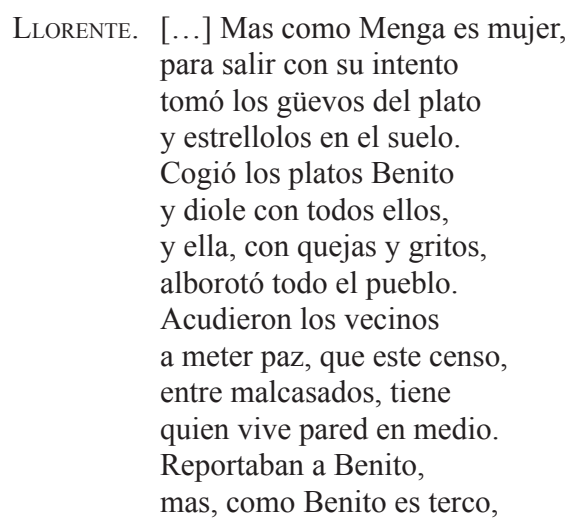

20. A pesar de la tregua, escuchamos aquí de parte de Benito la conocida sátira del matrimonio: «El que es malcasado / duerme mal y vive aprisa, / pues en la cama y la mesa / la lengua de una mujer / que a todo ha de responder, / si al marido ó́lla le pesa, / es el tormento sin duda / mayor que en el mundo ha habido, / como es gloria que el marido / sea sordo y ella muda» (p. 151). 


$\begin{array}{ll} & \text { dice que la ha de matar } \\ \text { o que ha de comer un güevo. } & \\ \text { Menga, con el alboroto } & \text { y los golpes, tiene el cuerpo } \\ \text { como una alheña molida, } \\ \text { y aun calentura sospecho. } \\ \text { Dice que se muere, a gritos } \\ \text { que los mete allá en los cielos; } \\ \text { mas porque esta vez no muera } \\ \text { vine yo a llamar al médico. } \\ \text { BenEFICIADO. } \\ \text { No hay dos tan malcasados } \\ \text { en dos semanas, por cierto. } \\ \text { Ni jamás mujer he visto } \\ \text { que rehúse tanto unos güevos (p. 153). }\end{array}$

La pieza concluirá con una breve escena cómica en la que Menga, tras la revisión del médico y la salida de Benito, pretende hacerse la muerta como último recurso para doblegar a su marido; al no lograr engañarlo y ser llevada en hombros por los clérigos camino de su entierro, decide «revivir», causando el terror gracioso de todos, y finalmente comerse hasta «una canasta entera» de huevos, con lo que se termina esta especie de reelaboración de fierecilla domada a lo rústico.

Otra pieza que debió tener una influencia inmediata muy importante en el texto cervantino fue la comedia Los malcasados de Valencia de Guillén de Castro, escrita probablemente entre 1599 y 1604, según señaló Courtney Bruerton (1944:125-126) ${ }^{21}$. Ya como se anticipa desde el título, la comedia basará buena parte de su argumento en la descripción de dos parejas frustradas en sus matrimonios, que hasta donde podemos ver se tratará por primera vez de nobles cortesanos en lugar de los rústicos que abundaron en las letras del siglo precedente. La obra desarrollará situaciones de enredo en el marco de otros elementos comunes de la Comedia Nueva, como la mujer en disfraz de hombre, billetes amorosos, criados graciosos y confusiones nocturnas, pero pondrá un énfasis especial, y poco frecuente en el teatro barroco, en la representación de las discusiones de las dos parejas protagonistas. Estos personajes, aunque situados en los parámetros de la comedia en tanto que caballeros y damas nobles, tendrán una caracterización jocosa que los aproximará a las figuras del donaire o incluso a los graciosos del entremés: un galán mujeriego y colérico, su mujer celosa, otro hidalgo pusilánime o flemático y su mujer autoritaria. He aquí solamente dos ejemplos, uno de cada pareja, entre otros varios que aparecen en la pieza y que explotan el sentido cómico de las peleas de matrimonios (en ambos casos, sobre respectivas sospechas de las esposas y los reproches consiguientes). La primera, del marido «femenino» Valerián y su mujer Eugenia: 


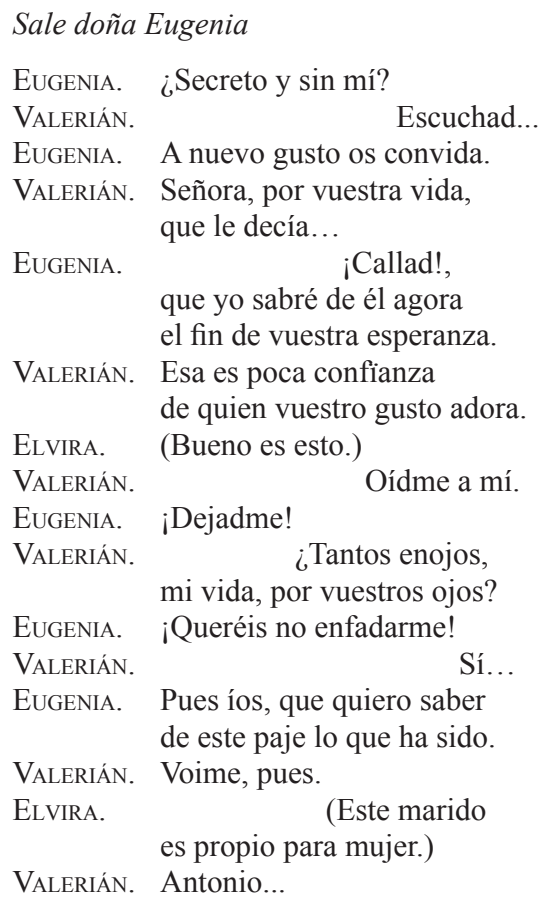

Señálale que calle [Eugenia a Valerián] (vv. 1133-1149, pp. 168-169).

La segunda será del galán mujeriego, Álvaro, y su mujer Ipólita, pelea en la que, a pesar de los antecedentes disolutos y la mala fama del esposo, en efecto no ha hecho nada en esta ocasión para la tormenta que se le viene encima, análoga a otra que ya había pasado en el primer acto:

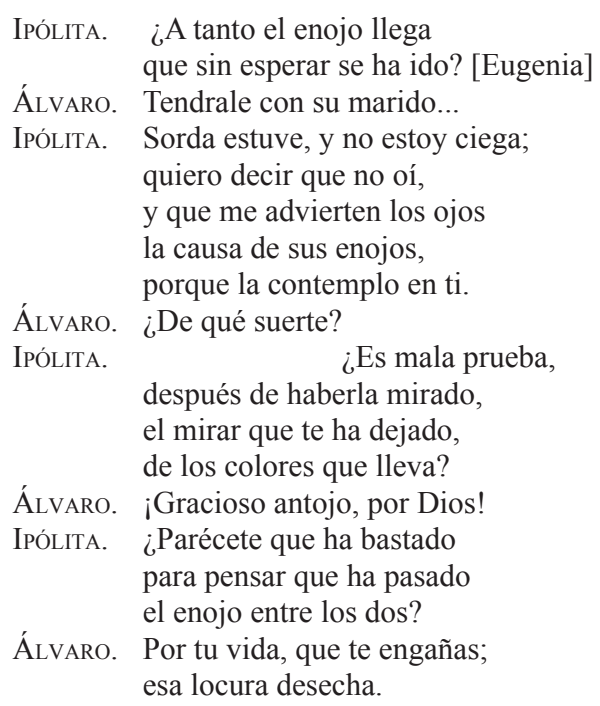


IPólita. No de balde esta sospecha se ha imprimido en mis entrañas; $\mathrm{y}$ ha hecho fundamento sobre quimeras pasadas.

Álvaro. Tus sospechas, mal fundadas, siempre estriban sobre el viento.

IPólitA. Tengo leal corazón.

Álvaro. Ya me cansas.

IPÓlITA. ¡Ay de mí! [...]

IPólita. Hasta el alma se me abrasa.

Álvaro. ¿Dónde vas? ¿En qué porfías?

IPóLITA. A llorar desdichas mías en un rincón de tu casa.

Álvaro. ¿Que ya lloras?

IPólita. No te asombres pues tú mismo lo quieres.

Álvaro. Así lloráis las mujeres como escupimos los hombres. ¿Dó vas?

IPÓLITA. $\quad$ Mi dolor profundo me lleva muerta.

Álvaro. ¿Qué dices?

¿Es bueno que escandalices con tus locuras al mundo? (vv. 1337-1380, pp. 183-186).

Al lado de este tipo de escenas, y de la descripción de los defectos de los cónyuges en otros momentos de la obra ${ }^{22}$, serán recurrentes igualmente las quejas sobre la figura del matrimonio, su carácter indisoluble, o su caracterización satírica negativa, como en otros textos en los que hemos identificado estos tipos cómicos:

Álvaro. Llorando va. ¡Oh, matrimonio!

Yugo pesado y violento, si no fueras sacramento diría que eras demonio (vv. 161-164, p. 75).

22. Por ejemplo, las burlas o quejas que emite Eugenia sobre su esposo Valerián, cuando declara con más énfasis su amor por Álvaro, con quien lo contrasta en sus rasgos masculinos: «Quieren las mujeres hombres / que no siempre se enternezcan, / y que lo que son parezcan / en las obras y en los nombres. / Y es muy cierto aborrecer / el que a sujetarse viene, / la que imagina que tiene / por marido una mujer. / Y así, yo de ti me fío, / de ti mi remedio espero; / por un marido me muero / que es opósito del mío», «y no mi Narciso bello, / aninfado y no feroz, / que lo espanto con la voz, / y con el pie lo atropello, / cuando en cualquiera ocasión / teme el ver que me alborote, / como si fuesen su azote / los ñudos de mi cordón. / Sabe el cielo que no puedo / querello, cuando me aviso / de que adora lo que piso, / más que por amor, de miedo», vv. 1165-1176, 1209-1220, pp. 171, 172173; y las que pronuncia el propio Álvaro por los celos terribles de su esposa: «Ahógame, ¿qué he de hacer? / si no es matar a mi mujer/ porque muera tu cuidado; / pues vesla por insufrible, / a mi gusto abominable; / en un tiempo me fue amable / cuanto agora aborrecible. / Pero tanto procuró, / con celos, con fuerza y brío, / cautivarme el albedrío / que libre el cielo me dio, / que, aborrecido, rompí / sus conjuros y su encanto, / y haré contigo otro tanto, / si haces otro tanto en mí», vv. 1430-1444, p. 190. 


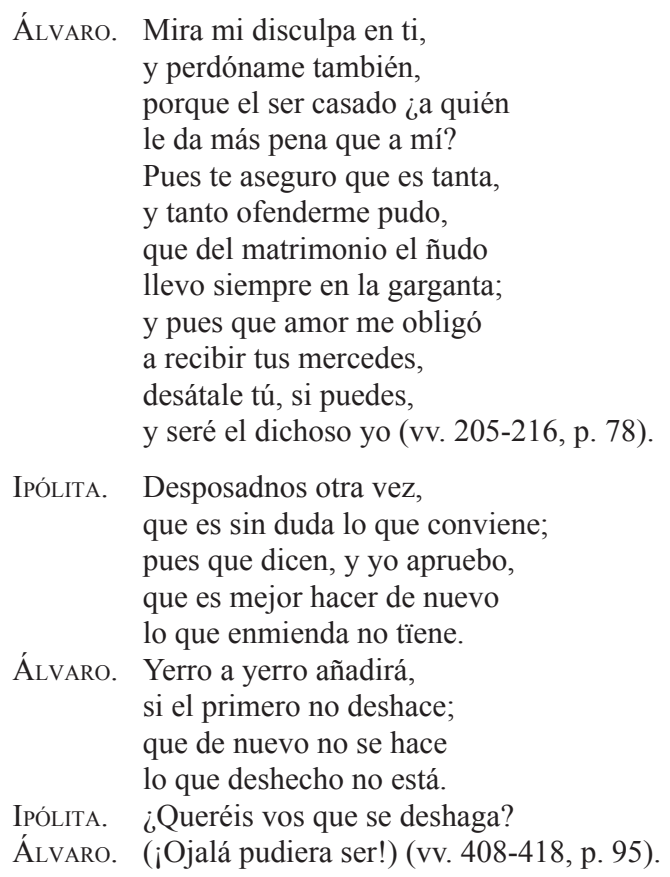

En la segunda parte, como se ha comentado, la comedia del poeta valenciano se desarrollará alrededor de los enredos que organiza la dama Elvira a propósito de las pretensiones amorosas de los cuatro protagonistas -y además, de dos criados graciosos-dejando ya en un plano secundario el motivo de los malcasados. Pero todavía cabe notar que el final de la comedia recupera otro de los elementos centrales que veremos en el entremés de Cervantes y su descendencia inmediata: la separación de los esposos. En la última escena, un alguacil aparece para anunciar que ambos matrimonios son inválidos, en un caso por haber organizado los actuales cónyuges el asesinato del anterior esposo, y en el otro por deficiencias en la dispensación eclesiástica. De manera que lo que parecía imposible a lo largo de toda la comedia se vuelve una realidad que consagra la sátira del matrimonio tormentoso. Esta sátira, más en línea con el sentido burlesco de los entremeses que con las bodas finales comunes en la Comedia Nueva, tendrá su colofón en el hecho de que, al igual que Elvira, los cuatro esposos deciden no volver a contraer nupcias nunca, a pesar de que «legalmente» están autorizados para ello. En la comedia de Guillén de Castro vemos así, además de un desarrollo teatral más complejo del personaje de la mujer escandalosa - o lo que también se entiende ya sin ninguna confusión por una malcasada ${ }^{23}$, lejana y radicalmente distinta de aquélla de la lírica del XVI-,

23. Esta continuará teniendo expresión en otras coordenadas literarias, como sucede en la segunda parte del Guzmán de Alfarache (1605) con la estupenda caricatura de la malcasada y su atormentado marido -en donde vemos claramente las huellas de Guevara, Rueda y Luján-, que vale la pena citar 
la presentación de varias parejas de malcasados, como será más frecuente a partir de estos años iniciales del siglo XVII, y la ampliación del rango social de estos protagonistas a los miembros de la nobleza ${ }^{24}$.

Después de observar, en el teatro y en la literatura, las posibilidades cómicas de las peleas de malcasados y su desarrollo extenso en la forma de una sola pareja o de un grupo de ellas, encontramos también algunos antecedentes importantes de la reducción de tales peleas a un desfile colectivo de breves escenas, como vemos el entremés de Cervantes. Tal recurso, el del desfile de figuras, aparece en varias tradiciones literarias anteriores -como «La nave de los locos» o las diversas formas de los «Hospitales de enfermos del juicio»-, y en estos años de comienzos del XVII ya ha tenido expresiones concretas dentro del género del entremés, según se ha indicado. De esas piezas, parece fundamental la participación de El triunfo de los coches de Gaspar de Barrionuevo en el diseño de la pieza cervantina. La obra del contador toledano, muy probablemente escrita alrededor del año de $1611^{25}$, es de signo contrario al planteamiento del Juez, ya que se trata justamente de personajes que van

por extenso: «Solo esto basta para que luego ella se arañe y mese, llamándose la más desdichada de las mujeres, que a Dios pluguiera que, cuando nació, su madre la ahogara, o la hubieran echado antes en un pozo que puéstola en tan mal poder, que sola ella es la malcasada, que Fulanilla es una tal y que su marido la trae como una perla regalada, que no es menos ella ni trujo menos dote, ni se casara con él, si tal pensara. Deshónralo de vil, bajo, apocado: que mejores criados tuvo su padre, que no mereció descalzarle la jervilla. “¡Desventurada de mí! ¡Cómo en ese regalo me criaron, para eso me guardaron, para que viniésedes vos a traerme de esta suerte, hecha esclava de noche y de día, sirviendo la casa y a vuestros hijos y criados! ¡Mirad quién! ¡Mi duelo! ¡Como si fuese tal como yo! Que sabe Dios y el mundo quién es mi linaje, don Fulano y don Zutano, el Obispo, el Conde y el Duque" -sin dejar velloso ni raso, alto ni bajo, de que no haga letanía-. Pues ya desdichado de él, si acaso acierta - que nunca le suceda tal a ninguno- a tener en su casa consigo a su vieja madre, a sus hermanas doncellas o hijos de otra mujer. "¡Para ellos es la hacienda que mis padres ganaron, con ellos la gasta, ellos la comen y a mí me tratan como a negra! Negra, y a Dios pluguiera que me trataran como a la de N., que por aquí pasa cada día como una reina, con una saya hoy, otra mañana"», II, pp. 394-396.

24. Probablemente esta obra influyó en la invención de las dos parejas protagonistas de la comedia El cuerdo en su casa, de Lope de Vega (1606-1608, según Morley y Bruerton), publicada en la Parte VI en 1615. Aunque el tema principal de la obra es la demostración de superioridad del sentido común del rústico frente a la soberbia del letrado, varias de las escenas tienen como elemento central los celos infundados de las respectivas esposas, que se traducen en diálogos muy parecidos a los de la comedia de Guillén de Castro, sin duda con la misma vena cómica. Sin ser estrictamente malcasados, en la comedia de Lope tendríamos por única ocasión discusiones conyugales de cortesanos y de rústicos en una misma obra.

25. En el entremés hay una alusión clara a una premática de prohibición de coches: «MONTANCHES. Antes entiendo que no tendrá coche, porque he oído decir que han mandado que no los haya. HiPólita. ¡Jesús, y qué mal mandado sería eso!», f. 275v. De las distintas disposiciones reales concernientes a coches desde al menos 1578, las más restrictivas de todas y las más cercanas a la publicación del entremés fueron las del año de 1611 (la primera en enero, y una declaración en abril): aunque no se llevó a efecto, como era habitual en tratándose de pragmáticas, la de enero de ese año prohibía del todo la factura de nuevos coches, exigía el registro de todos los existentes y vetaba su uso a todo aquel que no fuera el propio dueño y gente de su casa, por lo que no puede haber muchas dudas sobre la posible fecha de la pieza. De la misma opinión es Cotarelo, Colección de entremeses, p. LXIX. El entremés de Barrionuevo se publicó en la Parte VIII de Lope de Vega, en 1617. 
apareciendo ante un casamentero para pedirle que los concierte con una pareja. Pero su importancia radica en que no se trata de un desfile de figuras habitual, sino uno específicamente relacionado con el tema del matrimonio, con una intención satírica y cómica muy cercana a la de los entremeses de malcasados, y con la presencia central de una especie de fiscal que determina la acción de toda la pieza. De manera que también aquí, a pesar de su formulación contraria, veremos alusiones a las expectativas e inconvenientes sobre la vida matrimonial, e incluso algunas referencias a temas de nuestra tradición, como el maldecir al responsable del casamiento, los temores de las mujeres sobre los malos maridos, y el tipo de la pareja de viejo y moza, como apreciaremos con el Vejete y la Mariana cervantinos:

Montanches. La una es la Alfonsa.

Bilches. ¿La Alfonsa? No la conozco, ni sé quién es.

Montanches. ¿No? Una que acude de ordinario a Nuestra Señora de Atocha.

BILCHES. No quiero una mujer ultramuros.

Montanches. Aguarde. Cásese con una irlandesa.

BILCHES. ¡Quédelas a los diablos! Que no las puedo ver, porque son rezongonas, y piden cochiflonorrias, y nadie está bien con ellas, por ser impertinentes y prolijas. Y no las dan limosna.

Montanches. ¿No le contenta esta? Cásese con Mari Rubia, que es manca de una mano y le faltan las narices y un ojo.

Bilches. Pocas lisiones son esas para pedir limosna, y demás de eso no tendrá voz ninguna, y si alguna tiene, se le saldrá por las narices, y no la oirán de aquí allí (ff. 274r-274v).

Montanches. Trata de casarse, y tiene coche, y de los buenos que hay en la corte.

Doña Hipólita. ¿Coche y de los buenos que hay en la corte? Pues señor Montanches, de ninguna manera salga de aquí el señor don Plácido sin que vuestra merced me case con él.

MonTANCHES. No entiendo que le dará gusto a vuestra merced, porque es hombre de más de ciencuenta años.

DoÑa Hirólita. No mire vuestra merced en la edad, que así estaré más segura de que no me jugará la hacienda.

MonTANCHES. No hay que tratar de eso, que es hombre muy quieto y muy sosegado, pero el talle no le contentará a vuestra merced.

DoÑa HiPólita. ¿Por qué? ¿Tiene algún defeto?

MonTANCHES. Tiene aquí detrás un bultillo a manera de corcova que no le deja andar derecho, y parece que anda buscando turmas de tierra o alfileres.

Hipólita. No se le dé nada a vuestra merced, que con eso estaré segura que no me pondrá el cuerno ni me le cudiciarán las damas, y podré estar segura de celos (f. 277r) ${ }^{26}$.

Cervantes. ¿Vive aquí un hombre maldito?

26. A pesar de la analogía formal de la pareja de viejo y moza, lo cierto es que Doña Hipólita de Barrionuevo es un personaje completamente distinto a las que habíamos visto en el Arcipreste de Talavera o la Costanza, pues de entrada está dispuesta a tolerar todos los defectos físicos de su achacoso marido (queja central de sus antecesoras del XV y XVI) a cambio de poder conseguir el coche. 
Montanches. Este hombre debe de estar loco, ¿a qué diablos está diciendo?

Cervantes. ¿No vive aquí un hombre que casa?

Montanches. Pues válate el diablo, ¿qué tiene que ver un hombre que casa con un hombre maldito?

Cervantes. ¿Pues no es todo uno?

Montanches. ¿Cómo es todo uno?

Cervantes. Venga acá, yo se lo diré. ¿Él no sabe que, en riñendo dos casados, lo primero que dice la mujer al marido es: «iMaldito sea quien con vos me juntó!»? (f. 277v).

No obstante ser todos los personajes del entremés casaderos por voluntad, la escena final, protagonizada por la pareja central de Hipólita y don Plácido, será la representación de una pelea más de malmaridados, después de descubrirse el engaño que el viejo ha urdido para poderse casar, y además en ella aparecerá una vez más la idea del divorcio que veremos en la obra de Cervantes:

DoÑa HIPÓlita. ¿Qué es esto? Ven acá, muchacho, a dónde enviáis el coche?

Plácido. A su dueño, señora.

DoÑa Hipólita. ¿Luego no era vuestro? ¡Ay, triste de mí!

PlÁCIDO. Halo sido hasta agora, que estaba por casar, mas ya que estoy casado no lo he menester.

DoÑa HiPólita. ¿Cómo que no lo habéis menester? Pues siendo mancebo le habéis tenido, y agora que sois casado no lo queréis tener, ¿qué es la causa?

PlÁCIDO. Eso preguntaldoos a vos misma.

DoÑa HIPÓLITA. ¡Que hayáis vendido el coche! ¡Oh, maldito sea quien con vos me juntó!, que si no tuviérades coche yo no me casara con vos. Y lo que ha de hacer es mandarle traer luego al punto. ¡Donde no, yo pidiré divorcio!

PlácIDo. Eso juro yo, que no os casáredes vos conmigo si no tuviera coche (f. 278v).

Es en torno a todas estas coordenadas y materiales que Cervantes construirá los personajes y las situaciones de su entremés ${ }^{27}$. Además de los elementos vistos en los textos antiguos del XVI, en el entorno inmediato tanto en la

27. Hay otras referencias puntuales en el teatro de estos años de los motivos que nos ocupan. Por ejemplo, en la caricatura de los malcasados que hace el gracioso Tristán en El mármol de Felisardo (ca. 1596), de Lope: «Y advierte luego de dos / el más llano casamiento, / que aunque a Dios sirven también, / no es con aqueste descanso: / donde no hay hijos, no hay bien; / si los hay, ganado es manso. / Diles que durmiendo estén: / allí llora el pequeñuelo, / allí el otro pide pan, / allí el otro se va al cielo [...] ¿Pues qué si el casado tiene / mujer celosa? De un bronce / tener alma le conviene: / “¿Dónde fuistes a las once? / ¡Ved las horas que viene!” / "La tal, la cual, la bellaca, / la afeitada, sucia y flaca; / yo sabré lo que he de hacer", / que ni al dormir ni al comer / la furia un momento aplaca. / “Ay, mi dote! ¡Dalde cabo! / ¡Jugad, gastad, eso quiero! / ¿Qué trujistes vos? Ni un clavo”. / Porque el dote es el dinero / con que se compra un esclavo», pp. 1604-1605. 
comedia de Guillén como en Los huevos se ha desarrollado ya el potencial cómico de las discusiones de esposos y del personaje de la malcasada que informarán El juez de los divorcios; de la misma forma, en el entremés del contador Barrionuevo se ha mostrado ya el desfile de personajes en escenas breves discutiendo sobre el matrimonio y haciendo la resabida sátira sobre él. A esa imagen de los esposos desconcertados, y especialmente a la de la mujer mal acondicionada que hemos visto en numerosísimos textos remiten los personajes del entremés cervantino desde la primera intervención:

Vejete. Por amor de Dios, Mariana, que no almonedees tanto tu negocio. Habla paso, por la Pasión que Dios pasó. Mira que tienes atronada a toda la vecindad con tus gritos, y pues tienes delante al señor juez, con menos voces le puedes informar de tu justicia.

JuEz. ¿Qué pendencia traéis, buena gente?

MARIANA. Señor, ¡divorcio, divorcio y más divorcio, y otras mil veces divorcio! (p. 3).

Tanto en el caso de doña Mariana como de la Guiomar, al lado de las duras razones con que escandalizan la audiencia, su caracterización de malcasadas estará generalmente presentada en voz de sus maridos -en tono notoriamente guevariano, pero más a lo jocoso-y será la razón principal o la única que estos expondrán para solicitar su divorcio, a diferencia del catálogo de defectos de que ellas se quejarán en su turno ante el juez:

VEJETE. [...] Mal conocen vuesas mercedes a esta señora. Pues a fe que, si la conociesen, que la ayunarían o la santiguarían. Veinte y dos años ha que vivo con ella mártir, sin haber sido jamás confesor de sus insolencias, de sus voces y de sus fantasías, y ya va para dos años que cada día me va dando vaivenes y empujones hacia la sepultura; a cuyas voces me tiene medio sordo, y a puro reñir, sin juicio. Si me cura, como ella dice, cúrame a regañadientes, habiendo de ser suave la mano y la condición del médico. En resolución, señores, yo soy el que muero en su poder y ella es la que vive en el mío, porque es señora, con mero mixto imperio, de la hacienda que tengo (p. 5).

Soldado. Por esto solo merecía ser querida esta mujer. Pero debajo de este pundonor tiene encubierta la más mala condición de la tierra: pide celos sin causa, grita sin porqué, presume sin hacienda y, como me ve pobre, no me estima en el baile del rey Perico. Y es lo peor, señor juez, que quiere que, a trueco de la fidelidad que me guarda, le sufra y disimule millares de millares de impertinencias y desabrimientos que tiene $[\ldots]$ ¿Qué se me da a mí que seáis casta con vos misma, puesto que se me da mucho, si os descuidáis de que lo sea vuestra criada, y si andáis siempre rostrituerta, enojada, celosa, pensativa, manirrota, dormilona, perezosa, pendenciera, gruñidora, con otras insolencias de este jaez, que bastan a consumir las vidas de docientos maridos (p. 10).

Ya que la descripción de estos temperamentos malhumorados será siempre de parte de los sufridos maridos, no es necesario que se presente en escena la 
cuarta mujer, la placera, para que los espectadores tengan la misma pintura (escapando de esta presentación únicamente la Aldonza, esposa del cirujano):

Ganapán. Volví en mí, sané y cumplí la promesa, y caseme con una mujer que saqué de pecado. Púsela a ser placera; ha salido tan soberbia y de tan mala condición, que nadie llega a su tabla con quien no riña, ora sobre el peso falso, ora sobre que le llegan a la fruta, y a dos por tres les da con una pesa en la cabeza o adonde topa, y los deshonra hasta la cuarta generación, sin tener hora de paz con todas sus vecinas y apartadas. Y yo tengo de tener todo el día la espada más lista que un sacabuche para defendella; y no ganamos para pagar penas de pesos no maduros ni de condenaciones de pendencias. Querría, si vuesa merced fuere servido, o que me apartase de ella o por lo menos le mudase la condición acelerada que tiene en otra más reportada y más blanda (pp. 12-13).

Cervantes, así, saca partido cómico al personaje de la malcasada por una doble vía: por una parte, en las quejas casi idénticas de la mayor parte de los maridos; y por otra, en la forma de la expresión de las propias mujeres -más allá del contenido de sus parlamentos-, que debemos entender así que requieren de un gran histrionismo para hacer efectivas las acusaciones de los atormentados esposos y las llamadas al silencio del juez y otros personajes; histrionismo que no se requiere en el caso del vejete, el soldado, y al parecer tampoco del ganapán. El único personaje masculino que participará de este carácter revoltoso será el elocuente cirujano, que es quien tiene la intervención más breve de todas.

A la luz de los textos y los ejemplos mencionados, quedan más claros varios de los procedimientos con los que Cervantes escribe el primer entremés de su colección. Nuestro autor alude y utiliza un modelo cómico que seguramente es bien conocido en su época, y en el que hemos visto que no está asociado a estas alturas un tipo específico de personaje: solamente está definido de modo general el esquema de las peleas, las quejas respectivas de los cónyuges, y con algo más de detalle el carácter de la malcasada, pero pueden ser incluidos tanto villanos y rústicos como damas y caballeros cortesanos. En el ámbito de los malcasados literarios no es nueva la sucesión de parejas, que ha aparecido en la Constanza de Castillejo y en la comedia de Guillén de Castro, pero parece que Cervantes en este sentido se basa en el recurso del desfile de figuras que tendrá mucha fortuna en el entremés y que ya ha aparecido con una forma más cercana en el Hospital de los podridos y especialmente en el Triunfo de los $\operatorname{coches}^{28}$. Por esa causa seguramente, Cervantes asocia el argumento cómico

28. No es en principio intención de estas líneas tratar acerca de la fecha probable de escritura de este entremés cervantino. Los estudiosos han propuesto un amplio abanico de posibilidades, aunque la mayoría de ellos sitúa la escritura de estas piezas breves, a falta de mejores elementos de datación, en fechas relativamente cercanas a la publicación de las Ocho comedias (por ejemplo Cotarelo, 1968:107108), opinión que comparto al menos en lo que toca a El juez de los divorcios. Agustín de la Granja (1998), y con él Pérez de León, suponen que los entremeses cervantinos debieron ser escritos en un momento muy anterior, en los años finales del siglo XVII, principalmente por el recurso de la prosa. 
de las parejas desconcertadas a un conjunto más diverso de personajes; en este sentido, utiliza tanto tipos de larga historia, como el viejo y el soldado pobre - de los cuales solo el viejo tenía alguna relación con la tradición de malcasados, en su conjunción con la malmaridada joven-, como otros de más reciente configuración literaria en la España de Felipe III, como el cirujano barbero, el ganapán o la placera; a la familia de malcasados Cervantes parece sumar, así, el estamento que forma el grueso de la población de la villa y corte, los oficiales, dando otro paso más en la misma dirección que lo había hecho Guillén de Castro con la representación de parejas nobles.

Cervantes también puede ser el introductor de la figura del tribunal satírico en el género del entremés, que tendrá gran descendencia posterior, con su parodia jurídica concreta más allá de censores u otro tipo de fiscales burlescos que puedan haber aparecido en tradiciones anteriores. Además de eso, aunque en la tradición de malcasados se había sugerido de una o de otra forma la idea de la separación o el divorcio, es Cervantes quien asocia tal posibilidad al entorno de un juzgado - acaso por influencia del contexto real, o del teatro, o ambos-, algo que parecería una vinculación lógica pero a la que solamente el autor del Quijote llega a dar tal forma literaria en este género, si es que no tiene algún referente en otras formas de ficción.

Los elementos que ha sintetizado el héroe de Lepanto nuevamente en su entremés (las peleas de malmaridados, el desfile de figuras, el tribunal satírico) serán reproducidos al menos en otras dos piezas que recibieron influencia directa de la obrita de Cervantes. La más importante es el entremés El descasamentero, de Alonso Jerónimo de Salas Barbadillo, texto que, al igual que los cervantinos, nunca fue representado en las tablas, sino que fue solamente publicado en el libro Fiestas de la boda de la incasable malcasada, aparecido en Madrid hacia marzo de 1622. Este entremés es el primero del total de seis que se presentarán en la segunda parte del texto ${ }^{29}$ y que constituyen propiamente

Sobre el entremés que nos ocupa, esa posible datación casaría mal, pienso, con la influencia que me parece indudable del entremés del Triunfo de los coches, del que tenemos menos dudas que tuvo una vida efectiva en los corrales y que pudo ser escrito en fechas cercanas al inicio del año 1611. Por otra parte, la utilización de la prosa no debió de ser algo impensable en la escritura de entremeses hasta bien entrado el XVII, como atestigua el propio ejemplo de Barrionuevo, y el de Salas Barbadillo, quien todavía en 1622 publicaba tres piezas en prosa en sus Fiestas de la boda de la incasable malcasada (uno de los cuales se comenta a continuación).

29. Emilio Cotarelo, en su Colección de entremeses (1911) no recogió esta pieza, aunque sí las otras cinco del libro. Tampoco hace ninguna mención de ella Eugenio Asensio en el Itinerario del entremés (1971), a pesar de dedicar mucha atención al conjunto de entremeses de Salas -aunque su omisión puede ser derivada directamente de la de Cotarelo, en cuya antología basó buena parte de sus conclusiones-. El motivo de tal omisión puede ser la gran extensión del texto, que parecería aproximarlo antes a los diálogos narrativos que al teatro breve; también a ello contribuyen los dos paréntesis que interrumpen la acción del juzgado de divorcios para presentar sendos concursos poéticos de tipo académico. Pero no hay ninguna duda de que El descasamentero participa del carácter entremesil de las otras cinco piezas: por si no fuera determinante el esquema heredado de Cervantes, en el texto se describe expresamente su representación por parte de unos estudiantes extremeños, como las otras cinco obras. Recibe, además, el título de «comedia doméstica», y participa de un esquema a todas 
las fiestas a las que alude el título de la obra, después de una primera parte ocupada por una narración sobre una malcasada cortesana y soberbia -esta, más cercana a las malmaridadas de la lírica que a los malcasados cómicos, pero a lo satírico- ${ }^{30}$. Mucho más extenso que el texto cervantino, El descasamentero repite exactamente la presentación de un juez y dos oficiales que se ocupan de escuchar las querellas de personajes satíricos que solicitan el divorcio. La caracterización de este tribunal, sin embargo, dará una clave más para reconsiderar o al menos matizar toda posible lectura realista de la audiencia del entremés cervantino - especialmente cuando se quiere entender a través del estudio de la realidad legal de la época-: Salas Barbadillo hará de esta audiencia un tribunal parnasiano, enviado y sustentado en la jurisdicción del dios Apolo. Este elemento se expondrá de forma meramente nominal y no implicará ninguna otra diferencia entre los dos entremeses, ya que aquí también aparecerán protagonistas típicos de la sociedad y la corte española de principios del XVII; al no acudir a personajes literarios concretos, como Cervantes y otros ingenios, Salas sí construirá un planteamiento un poco más realista y contemporáneo en términos de la caracterización social de sus personajes. Pero a pesar de este tinte más claramente costumbrista, Salas muestra con su corte parnasiana que en buena medida el recurso al divorcio está vinculado al planteamiento fantástico de la sátira menipea (como ya se mostraba en torno a otros temas satíricos en el Hospital de los podridos), procedimiento que será frecuente en muchas otras piezas posteriores y que ya lo ha sido antes de este entremés en buena parte de la prosa de Salas ${ }^{31}$. En El descasamentero, Salas parece reconocer y anunciar en principio las escenas de malcasadas semejantes a las que hemos visto antes, especialmente en una breve escena con la dama Angélica:

Germano. Procurad que nuestro tribunal sea pacífico y quieto.

Ministro. Tribunal donde han de ser oídas mujeres, y mujeres malcasadas, estruendo espera y tumultuosos escándalos. O Vuestra Señoría renuncie su comisión en hombre mas paciente de oídos, o se prevenga a que se los han de taladrar gritos y alaridos femeniles (p. 57).

ANGÉLICA. No sé yo hablar despacio, y mucho menos poco. ¿Quién no ama a los perros, símbolo de la fidelidad, amigos más allá de la muerte (pues muchos han acompañado a sus dueños después de muertos en los sepulcros), valientes por los dientes, y no por las uñas, como los gatos, cuyo ladronicio es tan aborrecible? ¡Qué hábiles son, qué festivos!

luces conciente de parte de Salas de alternar tres entremeses en prosa (como El descasamentero, que inicia toda la serie), con tres entremeses en verso.

30. El rasgo más notable de esta distinción es que, aunque el destino final de esta dama es satírico burlesco, y también lo es la caracterización del galán con el que finalmente se casa, no se representan sus peleas ni recibe ella una caracterización jocosa más allá de la sátira de su soberbia.

31. Cervantes hará uso de este recurso de la menipea parnasiana en el Viaje del Parnaso, aunque no a propósito de tribunales satíricos. Por su parte, Salas acudirá a este esquema con mucha profusión desde el relato titulado «El curioso», incluido en la segunda parte de El caballero puntual, en el que sigue la influencia de los Ragguagli di Parnaso de Trajano Boccalini, y hasta su último libro, Coronas del Parnaso, publicado póstumamente en 1635; cfr. Robert H. Williams (1946). 
GERMANo. ¡Ministro, hacedla callar!

Ministro. Óigala, Vuestra Señoría.

Germano. ¿Tengo yo de sufrir tanto emperrado disparate? Miradla cómo con el coraje que ha recibido, porque la impido sus razones, se muerde y se despedaza, haciendo en sí más justicias que pudieran los mismos perros, si la trataran como al miserable Anteón (p. 66).

El descasamentero presenta otras variantes de importancia respecto al esquema de El juez de los divorcios: será a los hombres a quienes atribuirá mayormente un carácter quejoso, atildado o hazañero en la exposición de sus quejas, aunque no faltará alguna caricatura puntual de la malcasada en varias de las protagonistas ${ }^{32}$. También saca menos partido de las propias peleas entre esposos, basándose más en la exposición mutua de quejas, muchas veces sin presencia simultánea de ambos esposos, salvo en el caso del sastre cojo y su mujer, más cercanos ellos al resto de malcasados que se observan en Cervantes y otros textos:

ARDENIO. Señor, como nos descasen en cualquier partido, aunque no me esté tan bien como este, vendré con mucho gusto.

Marina. Esto ya toca en mi desprecio, y tanto que estaba por darle una vuelta que le dejara señalado de los pies a la cabeza. Mas ya lo está en entrambas partes, debiendo la señal de los pies a la naturaleza y la de la cabeza a mi ingeniosa industria.

ARDENIO. ¡De toda esa carga me libraré yo agora...!

MinISTRO. ¡Ah, señores!, adviertan que no es esta campaña donde salen desafiados maridos y mujeres, sino tribunal donde los juzgan, y así, estén con silencio y respeto.

Germano. Dejadlos que se digan, y entretendrémonos un poco mientras los gajes de esta ocupación nos los libran en moneda más provechosa.

ARDENIO. ¿Quiere ver Vuestra Señoría cuán ingrata es esta pícara que solía ser mi mujer, que la truje a mi casa en camisa y me trata de ese modo?

MARINA. ¿Quiere ver Vuestra Señoría en cuán mal pie entré en casa de este que solía ser mi marido, que no podía entrar en bueno, teniéndolos él tan malos? (p. 75).

Salas también parte, como se ha dicho, de un tipo de personajes distinto. Aquí los hombres no van a tener un revestimiento satírico típico, y en cambio las mujeres serán descritas en función de vicios de espíritu o manías concretas, diversificando el trazo monótono de la malcasada indómita que es común en otros autores, como lo es en Cervantes: una dama que gusta excesivamente de

32. Por ejemplo, sobre los maridos melindrosos, véanse los comentarios breves acerca de Mauricio, Fabio, y Claudio: «Él lo dirá, que ya viene, y tan poco sufrido de lengua y manos en los extremos que hace, que no parece marido», p. 61; «Señor, este debe de ser algún marido hazañero, madaleno y alindado, pues de otro modo fuera imposible que llegara en tan poco tiempo a desesperarse», p. 63; «Germano. Hermano, muy maricón me parecéis: enjugad las lágrimas y prevenid razones. Claudio. ¿Qué más razones que las lágrimas?», p. 67; y especialmente toda la caracterización de Conrado, al que tratan como muerto por su paciencia y falta de personalidad, pp. 79 y ss. 
pasear las calles, semejante en esto a la moza esposa del vejete cervantina; otra que tiene amor insano por los perrillos; otra por vestidos y afeites, y hasta una bachillera y poeta ${ }^{33}$. Salas añade a ello la sátira del casamentero, posiblemente recuerdo del entremés de Barrionuevo, y chistes constantes en toda la pieza acerca del carácter tormentoso, y destructivo para la República, del matrimonio ${ }^{34}$. Este conjunto de personajes tendrá, finalmente, una caracterización más cortesana, especialmente notoria en el decoro de su lenguaje, a diferencia de los tipos populares y su estilo coloquial que aparecen en El juez de los divorcios y que vienen desde el Arcipreste de Talavera. En este entremés Salas sí lleva a su tribunal a establecer condenas para los casos que se le presentan y en todos ellos será de concesión del divorcio, pero al lado de eso otorgará siempre sentencias satíricas, como es común en estos tribunales parnasianos, especialmente en el desenlace en el que el juez condena al último marido, el pusilánime Conrado, a un entierro burlesco ${ }^{35}$.

El segundo entremés que se ubica en el ámbito de influencia de la obra de Cervantes y de los temas aquí descritos es el anónimo Hospital de los

33. La descripción y caracterización de esta bachillera está planteada de inicio con el sentido cómico frecuente en las caricaturas de los poetas y «sabihondos», pero termina teniendo una valoración muy positiva por su gran ingenio y talento poético, y es por ello la única de las damas de este entremés que se salva de la sátira del autor.

34. Es la idea que más se machaca en el entremés. Véase, entre muchos ejemplos, el castigo a un casamentero: «Grande malicia es ser soltero y solicitar bodas ajenas. Confísquensele todos sus bienes para la Cámara de Apolo, y de hoy en adelante mando que ninguno pueda ejercer el oficio de casamentero sin ser primero casado, para que, conociendo con la experiencia lo que en semejante estado se padece, case a los que se pusieren en sus manos con más piedad, que esta consistirá en dar a las bodas poca prisa», pp. 70-71; y también la mayoría de epitafios jocosos que los protagonistas componen para el muerto Conrado. También aparece aquí la intervención de los vecinos, que hemos visto en otras obras, especialmente en la forma en que la enunció Pedro de Luján: «Callar, por no ser con nuestras voces entremés de los vecinos, que se ríen del llanto ajeno y se vuelven a sus casas sin haber remediado cosa alguna», p. 87; y más interesante, un episodio de hipotético cambio de esposas con aire rústico sugerido por el sastre, cuya mujer además se llama Marina (¿posible recuerdo de la Costanza?): «Mande Vuestra Señoría que troquemos, porque a mí me estará bien una mujer estéril, como a él una paridera y fértil. Germano. Hermano, yo no vengo a hacer cambalaches. Eso que me pedís no cae debajo de los términos de nuestra jurisdicción. Gran gitano me parecéis, pues sois tan truecaborricas», p. 74 .

35. Cabe mencionar que la pieza de Salas contiene una indicación que sugeriría como fecha de escritura el año de 1610. Es la alusión al tiempo de matrimonio de la dama Dorotea, casada en el año «de seiscientos» (p. 59) y en cuyo estado lleva «diez años», como se indica de forma reiterada páginas más adelante. No hay ningún otro indicio temporal en la obra, ni otro que corrobore esta posibilidad. Pero parece del todo improbable que el entremés pudiera haber sido escrito antes $-\mathrm{y}$ al margen- de las piezas de Barrionuevo y Cervantes, además de que no hay tampoco ningún rastro de él en las obras o documentos anteriores conocidos del autor, por lo que debe ser una mención sin pretensiones de exactitud cronológica. Creo, pues, que la fecha de escritura debe ser cercana al año de publicación, 1622, a diferencia de los indicios temporales que considero para otras de las obras aquí estudiadas. Por otra parte, la influencia del entremés de Barrionuevo también es indudable en otra pieza en prosa de Salas, la novela El coche mendigón, envergonzante y endemoniado, incluida en La casa del placer honesto (1620), en donde aparecen elementos como la mujer obsesionada por los coches, el engaño de fingir la posesión de uno para casarse con ella, la discusión entre esposos y la amenaza de divorcio. 
malcasados, atribuido a Quevedo por Astrana Marín, aunque posteriormente descartado del autor de los Sueños por Eugenio Asensio y José Manuel Blecua, y en fechas muy recientes, también por Ignacio Arellano y C. Celsa García Valdés en su edición del teatro completo del poeta. Esta pieza en verso, de fecha incierta pero muy probablemente escrita a mediados del tercer decenio del siglo ${ }^{36}$, reproduce el esquema de exposición de parejas mal avenidas y su deseo de curación en el marco de un hospital, influencia directa del Hospital de los podridos, lo que remitirá una vez más nuestros temas a la sátira menipea. En esta ocasión, dos timadores anuncian la creación de un hospital que cura la peste del mal casamiento ${ }^{37}$; ante las quejas de los distintos personajes que llegan a su consulta, tanto hombres como mujeres, aquellos ofrecen recetas burlescas o alegóricas, con mucha insistencia prescribiendo el apaleamiento de la mujer que ya se había asociado abundantemente al tema -por mal de nuestros pecados- desde los textos teatrales y de prosa del XVI. Como Salas, el anónimo autor se alejará un poco de la presentación en escena de la propia discusión entre los esposos, y se dedicará en su parte central a la sátira expresa del matrimonio y a las quejas burlescas, en donde veremos otra vez aparecer a algunos personajes del desfile de tipos, e incluso a los mismos que usó Cervantes en su entremés, como el viejo achacoso y el soldado poeta y jugador, al lado de un mozo casado con vieja (como la mismísima Costanza), y un cornudo. Todo ello antes de acabar con una falsa representación teatral para burlar al alguacil $\mathrm{y}$ al escribano que han ido a desmontar el fraude, y echarlos a palos:

AldonZA. Yo, mi señor dotor, tengo un marido.

Hispas. Si no hay más de uno, vos seréis honrada.

AldonZa. Escuche a la mujer más desdichada: es poeta, jugador y amancebado.

Hispas. Harto trabajo tiene el desdichado.

MENDR. ¿Qué oficio tiene?

Aldonza. Era abridor de cuellos.

Hispas. Agora puede abrir niños quebrados, que están ya los cuellos enterrados.

36. Además del rasgo formal de uso de endecasílabos (generalizado después del éxito del Miser Palomo de Hurtado de Mendoza, en 1618), en la pieza anónima se dan dos posibles referencias cronológicas. La primera de ellas es una alusión al veto de los cuellos, indicada en el diálogo con Aldonza, que en principio situaría al entremés en fecha posterior a 1623, cuando se emitieron las premáticas que prohibieron su uso; la segunda son los siguientes versos, que lo fecharían concretamente en el año de 1627, si corregimos una posible errata (el texto dice mil y quinientos son y veintisiete, pero eso no tendría sentido): «Hispas. ¡Muy buena está la fecha! Perales. ¿De qué modo? / Hispas. Vos con mil y seiscientos asentados, / y con los que ella tiene, seor vejete, / mil y seiscientos son y veintisiete»; cito el Hospital de los malcasados por la edición de Quevedo, Obras completas en verso, ed. Luis Astrana Marín, Aguilar, Madrid, 1952, pp. 621. Astrana Marín, por su parte, lo sitúa en 1624.

37. Esta pieza podría haber recibido influencia de El remendón de la naturaleza, entremés de Salas también incluido en las Fiestas en la que un impostor finge poder corregir los defectos físicos de las personas, motivo frecuente de la sátira áurea: barbas, calvas, pantorrillas; recuérdese que el tema del falso curador o remediador, a veces satírico, ya estaba en Castillejo y aparece con mucha profusión también en la prosa barroca. 
Aldonza. Hame jugado el dote que me dieron, y bien a mesa puesta y cama hecha.

Hispas. Y será lo más cierto estar deshecha.

AldonZa. Todo lo sufriera si callara (p. 620).

Mendr. Diga vuested agora.

NISE.

Que me place.

Sabrá vuesa merced que, aunque soy niña, me casé con un viejo de setenta de muy perfetas partes, tenga cuenta: nariz postiza, la cabeza en cueros, ojo de plata, zurdo y corcovado.

HisPas. Amiga, una mohatra habéis tomado.

Nise. Y no digo las faltas de la noche, porque tiene dinero y tiene coche.

MENDr. Daréisle seis unciones, enfermero, sufra, pues se casó por el dinero (p. 620) ${ }^{38}$.

LESMES. Señor, yo soy marido de una vieja; tiéneme acrebillado a puros celos; no me basta con ella palos, coces ni heridas, vuestasted me dé remedio.

Perales. La tranca de la paz se ponga en medio [el palo].

Mendr. No damos medicinas contra viejos (p. 621).

Como hemos podido ver en este recorrido, el entremés de Cervantes reúne varios elementos que se habían desarrollado en la literatura desde el siglo anterior, algunos provenientes de diversas obras en prosa, tanto de ficción como tratados de intención moral, y otros dentro del mismo género teatral ${ }^{39}$. En ese amplio corpus estaba ya sólidamente definido el propósito de tales recursos: al menos en el teatro y en la prosa narrativa, las peleas de casados siempre aparecen con una intención fundamentalmente cómica, que es la única que guía asimismo a Cervantes en este y en el resto de sus entremeses. Con otros elementos de análisis, se pueden confirmar aquí las interpretaciones que ya habían hecho estudiosos como Avalle-Arce y M. Bataillon sobre el sentido jocoso de El juez de los divorcios; pero mucho se ha escrito en sentido contrario después de aquellas aportaciones, y acaso no está de más insistir un poco en que las aproximaciones más adecuadas a la pieza cervantina son las que la consideran principalmente

38. Este entremés también acusa la influencia del cuadro final de El triunfo de los coches.

39. Además de la novela de Salas mencionada, en la prosa también se reflejarán varios de estos temas conyugales en la «Carta al autor, de un amigo suyo, pidiéndole consejo y arte para templar la terrible condición de su mujer», y su «Respuesta» satírica, incluidas en el libro primero de los Discursos morales de Juan Cortés de Tolosa (1617). Calderón, por su parte, utilizará buena parte de esta materia dramática y narrativa en el entremés de los rústicos Perote y Gileta -marido y mujer, naturalmente- inserto en las tres jornadas de La señora y la criada (1635), que ha sido notado y estudiado recientemente por Santiago Fernández Mosquera (2013). 
una obra de entretenimiento, sin ninguna pretensión ética ${ }^{40}$, según hacen ver sus modelos más claros. Nuestro autor no necesita proponer el establecimiento del divorcio: es una realidad de su sociedad, con parámetros y límites claramente definidos, como lo muestra el análisis de la legislación de la época y de su puesta en práctica. Pero no parece que esté dispuesto a aceptarlo por las razones disparatadas o absurdas que exponen sus personajes, porque todas ellas se basan en vicios del espíritu o en falta de virtud individual de cada miembro de la pareja. Aceptar la posibilidad de rompimiento del matrimonio cristiano por la mucha libertad de las mujeres, por su mal carácter, o porque los maridos hayan envejecido o tengan tachas morales menores sería, efectivamente, trivializar el matrimonio. En otros momentos nuestro dramaturgo sí aprovechará para proponer las condiciones de un casamiento virtuoso o los peligros de un matrimonio viciado por más graves pecados, como demostró precisamente Marcel Bataillon cuando trató de «Cervantes y el matrimonio cristiano». Y en este sentido probablemente El juez de los divorcios también participa más remotamente de esa «ortodoxia del XVI» acerca del matrimonio que señalaba el gran hispanista francés. No está muy lejos el tono general de la obra cervantina y sus conclusiones de la idea que ya apuntaba fray Antonio de Guevara, de nuevo en su Relox:

digo y afirmo que generalmente las mujeres son obligadas de amar a sus maridos, pues por su voluntad y no por fuerza se casaron con ellos, ca en semejante conflito (es a saber, si el casamiento le sale a la mujer avieso), no tiene tanta razón de quejarse del marido que la pidió, cuanta razón tiene de quejarse de sí misma que tal aceptó; porque los infortunios que por nuestra inadvertencia nos vienen, si tenemos mucha ocasión para llorarlos, también tenemos mucha razón para disimularlos (pp. 369-370) ${ }^{41}$.

Además de ello, la tradición de malcasados también nos hace notar que, a pesar de que en la ficción de la época está sancionado sin ningún problema el recurso del divorcio, en el entremés cervantino es este precisamente el que se evita y se satiriza, en sentido contrario a muchas otras piezas y pasajes en donde el sentido burlesco se centra en la vida matrimonial:

40. No es necesario descartar del todo interpretaciones más profundas sobre el significado moral de este sentido de lo cómico en la España del Alto Renacimiento y el Barroco (la representación misógina de la malcasada, el victimismo recurrente de los hombres, la pretensión cómica de los golpes a la mujer); pero ello ha de hacerse considerando los procesos de desarrollo de los modelos literarios y el carácter colectivo de esas formas de pensamiento, y no con base en una sola obra, como se ha hecho a veces con el entremés cervantino, cuyos antecedentes además explican suficientemente todos los aspectos de su creación.

41. Creo que es el sentido que está detrás de la reconvención del juez cervantino a Mariana, entre otros aspectos del entremés: «que yo no hallo causa para descasaros. Y pues comistes las maduras, gustad de las duras; que no está obligado ningún marido a tener la velocidad y corrida del tiempo, que no pase por su puerta y por sus días; y descontad los malos que ahora os da, con los buenos que os dio cuando pudo; y no repliquéis más palabra», p. 6. Con más claridad repite la idea Salas en El descasamentero: «Más cuerdo es de lo que pensé, porque cuando le vi aceptar este cargo le juzgué por loco, pues viene a tratar el remedio de aquellos que por su elección se metieron en el daño», p. 57. 
Mariana. [...] En los reinos y en las repúblicas bien ordenadas había de ser limitado el tiempo de los matrimonios, y de tres en tres años se habían de deshacer o confirmarse de nuevo, como cosas de arrendamiento, y no que hayan de durar toda la vida, con perpetuo dolor de entrambas partes.

JuEz. Si ese arbitrio se pudiera o debiera poner en prática, y por dineros, ya se hubiera hecho... (p. 4).

CiruJano. ¿Qué más pruebas, sino que yo no quiero morir con ella, ni ella gusta de vivir conmigo?

JuEz. Si eso bastase para descasarse los casados, infinitísimos sacudirían de sus hombros el yugo del matrimonio (p. 12).

Cervantes se ríe, como sus contemporáneos, de los malcasados gritones y ridículos, pero mucho se cuida de reírse del matrimonio, llevado tal vez por un profundo escrúpulo moral fácilmente constatable en sus textos más serios sobre el tema. Sin embargo, vuelvo atrás: identificar estos matices tampoco debe presuponer que la defensa del matrimonio es una tesis que Cervantes intenta demostrar con su entremés, como tampoco se debe adelantar ninguna hipótesis de las soluciones que en cualquier otro sentido vemos en los argumentos de Guillén de Castro, Salas Barbadillo o el resto de los autores aquí estudiados. Se trata solamente de una ficción literaria, más allá de la realidad jurídica, los detalles procesales o los distintos debates ideológicos de la época ${ }^{42}$, pues en $E l$ juez de los divorcios importa mucho menos la referencia al divorcio del título que la representación de las peleas entre estos personajes graciosos, como sucede en prácticamente todas las otras obras mencionadas. Además, a pesar de ser una realidad de la sociedad española, en el teatro breve la representación del divorcio no se basará casi nunca en aspectos históricamente comprobables, sino más bien en planteamientos que precisamente tendrán por objetivo poner en duda su autenticidad por medio del engaño, la alegoría o especialmente el planteamiento fantástico, como sucede también con el inverosímil tribunal divorciador de Cervantes.

En esta pieza, mucho más cómodo en la piel del entremesista que en la del poeta de la Comedia Nueva, nuestro escritor solamente reformula unos esquemas literarios de gran potencial cómico, y bien conocidos por sus lectores y público, para crear una obra de entretenimiento con algún contenido, acaso, de contramodelo de comportamiento - aspecto por lo demás común de cualquier sátira, aun la más abiertamente burlesca-, sin ninguna intención moral. Pero eso tampoco es una virtud menor.

42. Es posible, naturalmente, estudiar también las distintas formas de representación literaria del divorcio en esta época, pero creo que los tiros han de ir por otro lado, que no por las figuras de los entremeses. En este sentido, me parece de gran interés el tercer acto de la comedia de Lope $L a$ malcasada (1610-1615), en la que, aunque con las estilizaciones de la comedia urbana, se representa con detalle un proceso de divorcio por impotencia del marido, seguramente mucho más cercano a la realidad que lo que se nos representa en las piezas breves. Y en el ámbito palatino, también pueden ser de interés las comedias La reina doña María (1604-1608) y La discreta venganza (1620), en este último caso con referentes históricos concretos del repudio matrimonial representado en las tablas, que fue el de Alfonso III de Portugal. 


\section{BIBLIOGRAFÍA CITADA}

Albuixech, Lourdes (2008). «El matrimonio y la tradición de la malcasada en la narrativa pastoril española», Espéculo. Revista de Estudios Literarios. 38. Accesible en: http:// pendientedemigracion.ucm.es/info/especulo/numero38/malcasad.html

Alemán, Mateo (1987). Guzmán de Alfarache. José M. Micó (ed.) Madrid: Cátedra, 1987, 2 vols.

Aresti, Cristiana (2005). «La Farsa della Costanza de Cristóbal de Castillejo, un inedito nella Raccolta Pio Falcò di Savoia alla Biblioteca Estense Universitaria di Modena», en Memorie scientifiche giuridiche letterarie, Academia Nazionale di Scienze Letterarie e Storiche di Modena. Serie VIII, vol. VIII, 2, pp. 541-556.

Atienza, Belén (2004). «El juez, el dramaturgo y el relojero: justicia y lectura como ciencias inexactas en El juez de los divorcios de Cervantes», Bulletin of the Comediantes. 56, 2, pp. 193-217.

Auto de Clarindo, en Cuatro comedias celestinescas (1993). Miguel Ángel Pérez Priego (ed.) Valencia: Universidad de Valencia / Universidad de Sevilla / UNED, pp. 211-285.

Barrionuevo, Gaspar de (1617). Entremés famoso del triunfo de los coches, en Lope de Vega, Octava parte de sus comedias. Madrid: Viuda de Alonso Martín, ff. 274r-279r.

Bruerton, Courtney (1944). «The Cronology of the Comedias of Guillén de Castro», Hispanic Review. XII, pp. 89-151.

Cacho, María Teresa y Blanca Periñán (2006). «La Farsa de la Costanza recuperada», Rivista di Filologia e Letterature Ispaniche. IX, pp. 9-29.

Castillejo, Cristóbal de (2012). Farsa de la Costanza. Blanca Periñán y Rogelio Reyes (ed.) Madrid: Cátedra, 2012.

Castro, Guillén de (1976). Los malcasados de Valencia. Luciano García Lorenzo (ed.) Madrid: Castalia [1 $1^{\mathrm{a}}$ edición].

Cervantes, Miguel de (2012). El juez de los divorcios, en Entremeses. Alfredo Baras Escolá (ed.) Madrid: Biblioteca Clásica de la Real Academia Española, pp. 3-14.

Chevalier, Maxime (1983). Cuentos folklóricos españoles del Siglo de Oro. Barcelona: Crítica.

Chevalier, Maxime (1984). «La trayectoria del cuento folclórico en las letras españolas de la Edad Media al siglo XIX», Cuadernos para la Investigación de la Literatura Hispánica. VI, pp. 195-208.

Entremés de los huevos en Colección de entremeses, loas, bailes, jácaras y mojigangas, desde fines del siglo XVI a mediados del XVIII (2000). Emilio Cotarelo (ed.) (Madrid, Bailly Bailliére, 1911), Facsímil preparada por José Luis Suárez y Abraham Madroñal (ed.) Granada: Universidad de Granada, I, pp. 150-154.

Fernández Mosquera, Santiago (2013). «Entremeses empotrados en comedias: un ejemplo en La señora y la criada de Calderón». Rilce, 29, 3, pp. 654-668.

Fradejas, José (1978). «Varias versiones más de la fábula de la lechera», Cuadernos para la Investigación de la Literatura hispánica. I, pp. 21-30.

Frenk, Margit (2003). Corpus de la antigua lírica popular hispánica. México: UNAMFCE-El Colegio de México, 2003, 2 vols.

Guevara, fray Antonio de (1994). Reloj de príncipes. Emilio Blanco (ed.). Madrid: Turner.

Lauer, Robert (2005). «Las enfermedades de las malcasadas en los dramas de honor del Siglo de Oro», en El matrimonio en Europa y el mundo hispánico. Siglos XVI y XVII. Ignacio Arellano y Jesús María Usunáriz (ed.) Madrid: Visor, pp. 55-63.

Lorenzo Gradín, Pilar (2004). «La canción de malcasada en las tradiciones líricas romances: del contexto al texto», en De la canción de amor medieval a las soleares: profesor Manuel Alvar «In memoriam» (Actas del Congreso Internacional «Lyra minima oral III», Sevilla, 26-28 de noviembre de 2001). Pedro Manuel Piñero Ramírez (coord.) Sevilla: Universidad de Sevilla, pp. 189-208. 
Luján, Pedro de (1990). Coloquios matrimoniales. Asunción Rallo (ed.) Madrid: RAE.

Martínez Navarro, María del Rosario (2007). «Dos muestras del teatro cómico popular en Miguel de Cervantes y Cristóbal de Castillejo: estudio comparativo de El juez de los divorcios y Farsa de la Constanza», en Nuevas aportaciones a los estudios teatrales (del Siglo de Oro a nuestros días). Héctor Brioso y José V. Saval (ed.) Alcalá de Henares: Universidad de Alcalá, pp. 25-49.

Martínez de Toledo, Alfonso (1981). Arcipreste de Talavera o Corbacho. Michael Gerli (ed.) Madrid: Cátedra.

Milán, Luis (1874). El cortesano. Madrid: Imprenta Aribau.

Pérez de León, Vicente (2005). Tablas destempladas. Los entremeses de Cervantes a examen, Alcalá de Henares: Centro de Estudios Cervantinos.

Quevedo, Francisco de (1952). Obras completas en verso. Luis Astrana Marín (ed.) Madrid: Aguilar, pp. 618-622.

Restrepo-Gautier, Pablo (1995-1997). "“Y así a todos os recibo a prueba": risa e ideología en El juez de los divorcios de Cervantes», Anales Cervantinos. XXXIII, pp. 229-246.

Rueda, Lope de (1990). Pasos completos. Juan María Marín Martínez (ed.) Madrid: EspasaCalpe.

Salas Barbadillo, Alonso Jerónimo de (2002). El descasamentero, en Las fiestas de la boda de la incasable malcasada, María Bascuas Domínguez (ed.) tesis de licenciatura. A Coruña: Universidade da Coruña, pp. 54-94.

Timoneda, Juan (1993). Cancionero llamado Sarao de amor. Carlos Clavería (ed.) Barcelona: Delstre's.

Vega Carpio, Lope (2005). El mármol de Felisardo. Beatriz Aguilar y Benet Marcos (ed.), en Parte VI de Comedias de Lope de Vega. Victoria Pineda y Gonzalo Pontón (coord.) Lérida: Milenio-UAB, pp. 1571-1702.

Vicente, Gil (1996). Comedia del viudo, en Teatro castellano. Manuel Calderón (ed.) Barcelona: Crítica, pp. 113-151.

Williams, Robert H. (1946). Boccalini in Spain: A Study of His Influence on Prose Fiction of the Seventeenth Century. Menasha: George Banta.

Recibido: 20 de junio de 2014

Aceptado: 14 de noviembre de 2014

\section{Resumen}

En este trabajo se revisan varios de los referentes literarios, especialmente del siglo XVI, que pudieron servir como modelos para el entremés El juez de los divorcios de Miguel de Cervantes. Entre los primeros antecedentes teatrales de importancia se encuentran la Farsa de la Costanza, de Cristóbal de Castillejo, y algunas piezas de Lope de Rueda, además de pasajes breves en otras obras en las que vemos la representación cómica de peleas conyugales. Sin embargo, la prosa también tendrá un papel muy importante en varios de los motivos que se ven en la pieza cervantina, como la sátira del matrimonio y principalmente la descripción de la malcasada furiosa, como se observa en el Arcipreste de Talavera o en la obra de fray Antonio de Guevara y Pedro de Luján. En tiempos de Cervantes, estos temas se vuelven a retomar en el Entremés de los huevos, El triunfo de los coches de Gaspar de Barrionuevo o Los malcasados de Valencia de Guillén de Castro; y después de la publicación del entremés cervantino, en El descasamentero de Salas Barbadillo o el anónimo Hospital de los malcasados. Con este análisis se observan mejor varios de los elementos literarios que Cervantes imita de la tradición anterior, y queda de manifiesto el carácter esencialmente cómico de la pieza. 
Palabras clave: Miguel de Cervantes; Teatro español; Siglos XVI y XVII; Sátira del matrimonio; Malcasados cómicos.

Title: The starter of Cervantes's El juez de los Divorcios, and other pobres y pobras malcasados.

\begin{abstract}
In this work I survey some of the literary referents, mainly from XVI ${ }^{\text {th }}$ Century, that may have served as models for Miguel de Cervantes' short piece The Divorce Court Judge. Among the first important drama precedents are Cristóbal de Castillejo's Farsa de la Costanza and some pieces by Lope de Rueda, where we find the comical representation of conjugal struggles. However, prose has also a very important role in the development of many of the motives seen in the cervantine work, such as the satire of marriage, and principally the description of the grumpy ill-married woman; this is what we find for example in the Arcipreste de Talavera and the works of Antonio de Guevara and Pedro de Luján. In Cervantes' time, these themes are reformulated in plays like the Entremés de los huevos, Barrionuevo's Triunfo de los coches or Guillén de Castro's Los malcasados de Valencia; and, after the publication of Cervantes' piece, in Salas Barbadillo's El descasamentero and in the anonymous Hospital de los malcasados. With this study we can better identify many of the literary elements that Cervantes imitates from former traditions, and it becomes clear the essentially comical nature of the play.
\end{abstract}

Key Words: Miguel de Cervantes; Spanish Drama; XVI ${ }^{\text {th }}$ and XVII ${ }^{\text {th }}$ Centuries; Satire of Marriage; Ill-Married Comic Couples. 